1 The manuscript was submitted to the journal Sedimentary Geology, on Dec. 21 ${ }^{\text {st }}, 2020$, and

2 it was accepted for publication on Mar. 10 ${ }^{\text {th }}, 2021$ :

(The DOI of published article: https://doi.org/10.1016/j.sedgeo.2021.105901 )

\title{
Polygenetic mélange in the retrowedge foredeep of an active arc- continent collision, Coastal Range of eastern Taiwan
}

\author{
Larry Syu-Heng Lai ${ }^{a}$, Rebecca J. Dorsey ${ }^{\mathrm{a}}$, Chorng-Shern Horng ${ }^{\mathrm{b}}$, Wen-Rong Chicd ${ }^{\mathrm{c}}$ Kai-Shuan Shea ${ }^{\mathrm{e}}$, Jiun- \\ Yee Yen ${ }^{\mathrm{f}}$
}

${ }^{a}$ Department of Earth Sciences, University of Oregon, Eugene, Oregon 97403, United States

${ }^{b}$ Institute of Earth Sciences, Academia Sinica, Taipei 11529, Taiwan

'Department of Earth Sciences, National Cheng Kung University, Tainan 701, Taiwan

dDepartment of Earth Sciences, National Central University, Taoyuan 320, Taiwan.

${ }^{e}$ Central Geological Survey, Ministry of Economic Affairs, New Taipei 235, Taiwan

${ }^{f}$ Department of Natural Resources and Environmental Studies, National Dong Hwa University, Hualien

97401, Taiwan

*Corresponding author: Larry Syu-Heng Lai (larrysyuhenglai@gmail.com)

\section{Abstract}

The Plio-Pleistocene Lichi Mélange in the Coastal Range of eastern Taiwan offers an excellent opportunity to study processes of mélange development at the continent-ocean interface of an active arccontinent collision. This paper presents new results of detailed geologic mapping, lithofacies analysis, magneto-biostratigraphy, paleocurrent, and paleoslope analyses in the southern Coastal Range to investigate the origins and significance of this mélange. The results show that the Lichi Mélange consists of mass-transport deposits including well-stratified block-in-matrix beds (olistostromes), extra-formational blocks (olistoliths), and broken formation with abundant soft-sediment deformation features that transition laterally into distal 
29 mega-slump beds and pebbly mudstones (subaqueous debrites). Abundant observations of depositional

30 contacts and interbedding of mélange with contemporary (ca. 4-1 Ma) flysch units of the Fanshuliao and

31 Paliwan formations confirm their sedimentary origin. Compacted sedimentological shear fabrics in

32 olistostromal facies are broadly parallel to internal stratification and bedding, and are readily distinguishable

33 from cross-cutting brittle fault zones related to post $\sim 1$ Ma west-vergent thrust faults. Paleoslope and

34 paleocurrent analyses record down-slope gravity-driven transport toward the east and southeast.

The data provide evidence for a polygenetic origin of the Lichi Mélange, in which sedimentary masswasting deposits are overprinted by younger tectonic shear zones. Slide blocks, conglomerate clasts, and

37 detrital sand were all derived from an eroding source in the east-vergent eastern retrowedge of the Taiwan 38 collisional orogen. The source area included tectonically accreted fragments of the two converging plates that 39 represent shallow-crustal equivalents of the Miocene Yuli Belt and Eastern Slates exposed in the modern 40 Central Range. Reconstructed stratigraphic panels record eastward progradation of olistostromal facies over 41 distal basinal flysch deposits, which we infer resulted from eastward (oceanward) migration of a steep 42 submarine slope at the leading edge of the retrowedge orogenic front. Thus, the Coastal Range basin evolved as a migrating retro-foredeep basin that formed on top of older, pre-collisional volcanic arc and forearc crust.

44 These results demonstrate a unique type of sedimentary basin that is formed and then rapidly inverted at a 45 convergent continent-ocean interface during the transition from intra-oceanic subduction to arc-continent 46 collision. This revised history of the Lichi Mélange provides a new perspective on the dynamics of rapid crustal 47 mixing and tectonic recycling at the convergent suture of an active arc-continent collision system.

\section{Keywords}

50 Arc-Continent Collision, Taiwan Coastal Range, Lichi Mélange, Olistostrome, Retrowedge foredeep basin 
This is a postprint submitted to the EarthArXiv by Larry Syu-Heng Lai

\section{Introduction}

"Mélange" in geology is a non-genetic lithological term defined as a mappable and chaotic rock unit consisting of extra-formational (exotic) blocks embedded in highly mixed and disrupted matrix (i.e., block-inmatrix fabrics) (Greenly, 1919; Hsü, 1968; Cowan, 1985). Mélanges form by large-scale stratal disruption via tectonic, diapiric, or sedimentary processes, or a combination of these processes (i.e., polygenetic) (Raymond, 1984, 2019). They provide insights into the kinematics of crustal deformation and rock mixing at active plate margins, and therefore are useful for reconstructing continental growth over deep time in tectonically active settings (Dilek et al., 2012). Processes of mélange formation at the continent-ocean interface of arc-continent collision zones are particularly controversial and poorly understood due to the relative paucity of wellpreserved mélange records from ancient arc-continent collision zones globally (e.g., Festa et al., 2010), despite a few recent advances in a Neoarchean arc-continent collision system of the North China Craton (e.g., Wang et al., 2019; Kusky et al., 2020). The low preservation potential of mélanges at suture zones likely reflects the short lifetime (often $\sim 5-15 \mathrm{Myr}$ ) of arc-continent collision systems and rapid crustal erosion that occurs after the forearc crust is accreted in the retrowedge of arc-continent collision suture zones (Draut and Clift, 2013). To address these challenges, many studies have focused on active arc-continent collision orogens where young or active mélange generation can be directly observed (e.g., Harris and Audley-Charles, 1987; Huang et al., 2000). However, the genesis of these mélange units remains debated in part due to inconsistent definitions of "mélange" that lie at the center of controversies over tectonic models in many orogenic belts (Festa et al., 2012; Raymond, 2019). Growing evidence suggests that microscopic to outcrop-scale internal shears and block-in-matrix fabrics cannot be used as definitive criteria to distinguish mélange formation by faulting, diapirism, or gravitational processes (Raymond, 1984; Ogata et al., 2012; Wakabayashi, 2019), because mechanical styles of stratal disruption and brecciation depend on local physical properties (e.g., permeability, strength), which in turn depend on degree of consolidation, fluid content, pressure, temperature, and rate of structural loading and deposition (Michiguchi et al., 2011; Ogata et al., 2014; Festa et al., 2019). In 


\section{This is a postprint submitted to the EarthArXiv by Larry Syu-Heng Lai}

addition, recycling and incorporation of juvenile crustal materials via episodic tectonic and/or sedimentary processes commonly overprint older features at the boundary between advancing orogenic fronts and adjacent sedimentary basins (Festa et al., 2016; Moore et al., 2019; Ogata et al., 2019a). As such, interdisciplinary constraints from geologic mapping, stratigraphic analysis, kinematic study, etc. are required to advance our understanding of mélange formation in arc-continent collision zones.

The Lichi Mélange in the Coastal Range of eastern Taiwan (Fig. 1) is widely considered a classic example of mélange formed in an arc-continent collision suture, but its origin is poorly understood and thus still a matter of debate (Fig. 2). Prior studies have documented evidence in support of both sedimentologic (e.g., Liou et al., 1977; Page and Suppe, 1981) and tectonic (e.g., Chen, 1997b; Chang et al., 2000, 2001) processes of rock mixing, suggesting a possible polygenetic origin for the Lichi Mélange. However, the question of whether tectonic shearing or sedimentary (olistostromal) emplacement was the primary mode of shearing to form the Lichi Mélange remains unresolved. Such controversy is related to alternate models for basin evolution recorded by Plio-Pleistocene sedimentary rocks in the Coastal Range. According to the prevailing hypothesis (Fig. 2A), the Coastal Range is underlain by relatively little-deformed volcanic islands and adjacent forearc, intra-arc, and backarc basins (e.g., Teng, 1987; Huang et al., 1995; Chen, 1997a; Song and Lo, 2002), and the Lichi Mélange formed by tectonic shearing in a mega-thrust belt during large-scale forearc shortening (Chen, 1997b; Chang et al., 2001; Huang et al., 2008, 2018). Other studies suggest an olistostromal origin for the Lichi Mélange and consider the main body of the mélange to be part of a genetically related sedimentary sequence (e.g., Liou et al., 1977; Page and Suppe, 1981; Barrier and Muller, 1984) that filled a syn-orogenic flysch basin and was later tectonically inverted (e.g., Dorsey, 1988; Lundberg and Dorsey, 1988) (Fig. 2B). The second hypothesis postulates that the basin is deformed by large thrust faults due to strong crustal shortening, and the modern topography of the Coastal Range reflects the areal distribution of young structures and antiformal culminations rather than intact volcanic islands (Dorsey, 1992; Thomas et al., 2014). 
This is a postprint submitted to the EarthArXiv by Larry Syu-Heng Lai

The origin of the Lichi Mélange is likely also related to the formation of the late-Miocene Yuli Belt, an exhumed greenschist-blueschist facies metamorphosed mélange in the Central Range of Taiwan, located

101 directly west of the Coastal Range (Fig. 1A). Recent studies of the Yuli Belt propose numerous tectonic models 102 to explain mélange formation and rapid exhumation at the collisional plate suture (e.g., Chen, W.-S. et al., 103 2017; Conand et al., 2020). Thus the Lichi Mélange sits at the center of ongoing debate over processes of 104 mélange formation during accretion of oceanic arc crust, mechanisms of tectonic recycling in arc-continent 105 collision suture zones, and processes that drive growth of continental lithosphere through time (Clift and 106 Vannucchi, 2004). High-resolution age constraints, geologic mapping, process-based sedimentology, and 107 stratigraphic studies are therefore needed to resolve long-standing uncertainty and debate over the origins of 108 the Lichi Mélange.

For this study we conducted detailed geologic mapping, lithofacies analysis, measured sections, magneto-biostratigraphy, paleoslope and paleocurrent analyses to test hypotheses for sedimentary versus

111 tectonic origins of the Lichi Mélange. The results are systematically compiled below and applied to interpret 112 the basin-filling history, reconstruct basin geometry, and evaluate the role of the Lichi Mélange in the evolution 113 of the Taiwan collisional orogen.

\section{Geological background}

The island of Taiwan is an active arc-continent collisional orogen produced by oblique convergence

117 between the Eurasian continental margin and Luzon Arc on the Philippine Sea plate (Fig. 1) (Suppe, 1984; Yu 118 et al., 1997). The orogen is characterized by a low gradient west-vergent prowedge thrust belt in the west and 119 a steep east-vergent retrowedge in the east, separated by a high drainage divide that parallels the major 120 structural fabrics (Fisher et al., 2007). The major morphotectonic units of Taiwan include: (1) Pliocene to 121 modern pro-foreland basin and west-vergent thrust belt in the western Taiwan Strait, Coastal Plain, and 122 Western Foothills; (2) deformed low-grade Eocene to Miocene meta-sandstone and argillite in the Hsueshan 
This is a postprint submitted to the EarthArXiv by Larry Syu-Heng Lai

123 Range and western Central Range; (3) older metamorphic continental basement in the Tailuko Belt; (4) 124 greenschist-blueschist facies mafic to ultramafic metamorphic rocks and associated meta-sediments in the 125 eastern Central Range (Yuli Belt and Eastern Slates); and (5) accreted volcanic rocks of the Luzon Arc and 126 overlying deformed sequence of unmetamorphosed flysch deposits in the Coastal Range (Teng, 1990; Chen, 127 W.-S. et al., 2017). Estimates for the age of onset of collisional mountain building in Taiwan vary from about $128 \quad 6.5$ to $12.5 \mathrm{Ma}$ based on stratigraphic evidence for flexural loading in the pro-foreland basin and earliest 129 introduction of continental material into the trench (e.g., Lin et al., 2003; Tensi et al., 2006; Chen et al., 2019). 130 Despite these differences, it is widely agreed that major orogenic uplift, crustal thickening and tectonic 131 exhumation began at ca. 5 Ma. Pulses of accelerated exhumation occurred at ca. 1.5-2.0 Ma and 0.5 Ma as 132 indicated by abrupt changes in sedimentation rate and sandstone petrography in syn-orogenic basins (Dorsey, 133 1988; Teng, 1990; Nagel et al., 2014; Chen et al., 2019), timing of pressure-temperature dependent 134 metamorphism (Beyssac et al., 2008; Sandmann et al., 2015; Keyser et al., 2016), and bedrock cooling history 135 based on thermochronologic studies (Lee et al., 2015; Hsu et al., 2016).

137 (e.g., Horng and Shea, 1996; Chen, 2009; Huang et al., 2018; Lai, L.S.-H. et al., 2018), regional structures 138 (e.g., Chen, W.-H. et al., 2015; Lai and Teng, 2016), and basin style and geometry (e.g., Teng, 1987; Lundberg 139 and Dorsey, 1988; Huang et al., 1995; Chen et al., 2019). In addition, the term "mélange" has been defined 140 differently in published analyses and geologic maps (e.g., Hsu, 1956; Page and Suppe, 1981; Barrier and 141 Muller, 1984; Chen, 1997b; Chang et al., 2000; Chen, W.-H. et al., 2017; Huang et al., 2018), resulting in 142 ambiguous tectonic interpretations for eastern Taiwan. In the following sections, we present a standardized 143 lithostratigraphic framework and rock classification scheme for coherent (non-mélange) strata in the Coastal 144 Range based on a synthesis of classic and recent published studies. We then summarize existing knowledge of 145 regional structures in the southern Coastal Range, current models for the Lichi Mélange and basin evolution, 146 and provide standard definitions and stratigraphic nomenclature to be used in this paper. 
This is a postprint submitted to the EarthArXiv by Larry Syu-Heng Lai

\subsection{Non-mélange strata and structures of the Coastal Range}

Miocene rocks representing arc and forearc crust in the Coastal Range are unconformably overlain by

a thick $(4-7 \mathrm{~km})$ section of Plio-Pleistocene synorogenic marine flysch and conglomerate (Fig. 3). The

151 Tuluanshan Formation is defined as all volcanic and volcaniclastic rocks beneath the unconformity, including 152 the Chimei Igneous Complex ( 15-9 Ma), Shihmen Volcanic Breccia, and older Shihtiping Tuff ( 15-6 Ma) 153 (Chen, 1997a; Song and Lo, 2002; Lai et al., 2017). A 2 Myr time gap at the basal unconformity is 154 characterized by an abrupt change in depositional age, cementation, clay mineralogy, and truncated normal 155 faults that are restricted to the Tuluanshan Formation beneath the unconformity (Barrier and Angelier, 1986; 156 Dorsey, 1992). Field and stratigraphic analysis for this study shows that the age gap is partly occupied by an eastward-younging thin discontinuous sequence comprised of the Biehchi Epiclastic Unit ( 4 Ma), Kangkou Limestone ( 5-3 Ma), and younger units of the Shihtiping Tuff ( 4.2 Ma). (see details in Section 6.1)

The synorogenic Plio-Pleistocene succession of marine flysch and conglomerate in the Coastal Range records unroofing of metamorphic rocks in the Central Range orogen as documented with changes in 161 abundance of metamorphic lithic fragments (e.g., Teng, 1979; Dorsey, 1985; Chen et al., 2019), illite 162 crystallinity (Buchovecky and Lundberg, 1988; Dorsey et al., 1988; Yao et al., 1988), and reset detrital 163 thermochronometers (Kirstein et al., 2009, 2014). Earlier stratigraphic studies named these deposits the 164 Takangkou and Chimei formations (Hsu, 1956), or collectively the Takangkou Formation (e.g., Page and 165 Suppe, 1981; Chang et al., 2000; Huang et al., 2008; Chen, W.-H. et al., 2015). Definitional problems and 166 inconsistencies led to a newer nomenclature that subdivides the section into the Fanshuliao and Paliwan 167 formations (Teng, 1987; Chen, 2009). The Fanshuliao Formation contains thick slumped and chaotic horizons 168 in mudstone and fine-grained turbidites, with sand composed of volcanic lithic fragments, plagioclase feldspar, 169 quartz sand, and carbonate bioclasts (Teng, 1980; Teng et al., 2002). The Paliwan Formation consists of thin170 to thick-bedded turbidites and submarine conglomerates with abundant low-grade metamorphic lithic 


\section{This is a postprint submitted to the EarthArXiv by Larry Syu-Heng Lai}

171 fragments and only minor volcanic clasts (Teng, 1982; Chen, 1997a). The base of a widespread pebbly 172 mudstone layer (Pm3) defines the contact between the Fanshuliao and Paliwan formations in the southern 173 Coastal Range (Wang and Chen, 1993; Chen, 2009). Recent geologic mapping and stratigraphic analysis 174 permits further subdivision based on recognition of multiple widespread marker beds of pebbly mudstone and 175 tuffaceous turbidites (Fig. 3) (Lai and Teng, 2016; Lai, L.S.-H. et al., 2018).

The structure of the Coastal Range is dominated by large-displacement imbricate west-vergent thrust 177 faults and associated regional-scale folds (Wang and Chen, 1993). Rapid uplift rates (e.g., Hsieh and Rau, 2009; Chen et al., 2020), kinematic analyses (Barrier and Angelier, 1986; Lin et al., 1999), and modern seismicity (Angelier et al., 2000; Lee et al., 2006) provide evidence for ongoing active deformation and crustal thickening in the Coastal Range. Of the total Philippine Sea - Eurasian plate convergence rate $(\sim 82-90 \mathrm{~mm}$

$181 \mathrm{yr}^{-1}$ ), roughly $60 \mathrm{~mm} \mathrm{yr}^{-1}$ shortening is absorbed by convergence in the Coastal Range and offshore structures to the east ( $\sim 60 \mathrm{~km})$ in the past $\sim 1 \mathrm{Myr}$ (Reed et al., 1992; Tsai et al., 2015; Hsieh et al., 2020).

In the southern Coastal Range, several west-vergent thrust faults and three large plunging folds control the distribution of map units (Fig. 4) (Hsu, 1956; Wang and Chen, 1993; Lai and Teng, 2016). Among these structures, only the Longitudinal Valley fault is considered to be currently active (Angelier et al., 2000; Lee et

Chen, W.-H. et al., 2017), but dipping depositional contacts and continuous stratigraphy suggest the absence

191 West of there we have traced a 100-300 m wide belt of 5-10 m wide fault zones with fault gouge and brittle 192 shears aligned with the northern Tuluanshan fault, which we interpret as the southern Tuluanshan fault where 193 it cuts the Chungye river (CYC) and the Mukeng river (MKC) sections. (see details in Section 5) 
This is a postprint submitted to the EarthArXiv by Larry Syu-Heng Lai

\subsection{Lichi Mélange}

The Lichi Mélange, originally named "Raikoka Formation” or "Lichi Formation” (Ooe, 1939; Hsu, 1956), “consists mainly of poorly stratified mudstone in which some large or small rock fragments or blocks of hard greyish sandstone, gabbro, serpentin(ite), and a little slate are present" (Hsu, 1956). The mélange contains pervasive shear fabrics in poorly consolidated scaly mudstone and block-in-matrix textures (Chen, 1997b; Chang et al., 2000; Chen, W.-H. et al., 2017; Huang et al., 2018). Other block lithologies include andesite, volcaniclastic rock, limestone, ophiolite-bearing sedimentary rocks, amphibolite, low-grade metasandstone, and flysch blocks similar to the Fanshuliao and Paliwan formations (Liou et al., 1977; Page and Suppe, 1981; Sung, 1991). Clay minerals in the matrix are illite with relatively abundant kaolinite, in contrast to illite- and chlorite-rich Fanshuliao and Paliwan formations, suggesting different sediment source rocks, routing systems, weathering conditions, or mixing processes (Lin and Chen, 1986). Depositional contacts and shear zones linked to soft-sediment deformation and post-depositional thrusting suggest a complex mixture of tectonic and sedimentary rock-mixing products (e.g., Page and Suppe, 1981; Chang et al., 2000).

Despite previously published evidence for both tectonic and sedimentary origins to the Lichi Mélange, two alternate hypotheses describe the primary mode of rock mixing as either tectonic or sedimentologic (Teng, 1981; Chen, 1991; Huang et al., 2018) (Fig. 2). The currently prevailing hypothesis postulates that the Lichi Mélange formed by shearing of older forearc-basin sediments in a post-depositional mega-thrust zone (Chang et al., 2000, 2001; Huang et al., 2000, 2008, 2018; Chen, W.-H. et al., 2017), consistent with earlier models for deformation in a subduction-accretion complex (Fig. 2A) (e.g., Biq, 1977; Teng, 1981; Hsü, 1988; Chen, $1991,1997 b)$. In this framework, zones with varying degree of stratal disruption and rock mixing $\alpha-\delta$ scheme of Raymond (1984) are all mapped as Lichi Mélange (Chang et al., 2000, 2001; Huang et al., 2008; Chen, W.H. et al., 2017), and these mélange zones are defined as being bounded by discrete brittle thrust faults (Wang and Chen, 1993; Chen, 1997b). Thick segments of relatively coherent strata ( $\alpha$ and $\beta$ ) are thus interpreted to be fault-bounded slivers of originally coherent sedimentary rocks, and exotic blocks (ophiolitic, volcanic, 


\section{This is a postprint submitted to the EarthArXiv by Larry Syu-Heng Lai}

219 volcaniclastic rock types) are considered to be tectonically emplaced structural fault slices (Huang et al., 2008, 220 2018). Field observations reveal brittle scaly foliation and shear fabrics near the west-vergent Longitudinal 221 Valley fault and Tuluanshan fault, particularly in the Powhua and Luye area (Chen, 1997b; Chang et al., 2000, 222 2001). Foraminifera biostratigraphic data are proposed to support a depositional age of 3.35 to 8.5 Ma for 223 structurally disturbed strata in the Lichi Mélange, generally older than nearby exposures of the Fanshuliao and 224 Paliwan formations ( 4-1 Ma) (Huang et al., 2008, 2018; Chen, W.-H. et al., 2017). Unresolved challenges 225 to this hypothesis include: (1) definition of mélange units that are based on genetic interpretations, making it difficult to assess the potential role of gravity-driven processes; (2) lack of consistent criteria for identifying tectonic faults; (3) contacts that were reported as depositional in original studies (Chang et al., 2000, 2001) or later work (Lin et al., 2008) remain unexplained; and (4) interpreted depositional ages of mélange matrix that are inconsistent with prior studies of calcareous nannoplankton biostratigraphy (see below).

A second group of studies interprets the Lichi Mélange as a complex of submarine-slide deposits derived from the steep fault-bounded western margin of the basin (e.g., Hsu, 1956; Wang, 1976; Ernst, 1977;

Ho, 1977; Page and Suppe, 1981; Barrier and Muller, 1984). In this hypothesis, submarine slide blocks (olistoliths) are interbedded with and pass laterally into flysch facies of the Fanshuliao and Paliwan formations, and were later overprinted (tectonically reworked) by post-depositional brittle tectonic faults. This multi-stage hypothesis is supported by analogue modeling (e.g., Malavieille et al., 2016, 2021) and seismic reflection studies of offshore chaotic bodies in the North Luzon Trough that are proposed as a modern equivalent of the Lichi Mélange (e.g., Huang et al., 1997; Chi et al., 2014). Within this framework, the Lichi Mélange, or "Lichi Formation" (Hsu, 1956), was originally defined as chaotic disrupted broken formation and mixed block-inmatrix rocks (mélange) with locally interbedded coherent layers of conglomerate, pebbly mudstone, slump beds, mudstone, and flysch (Liou et al., 1977). Few undisputed depositional contacts have been reported 241 between mélange and coherent strata associated with soft-sediment stretching, bending, folding, or 242 fragmentation of blocks (Page and Suppe, 1981; Li, 1984). Early studies showed that calcareous nannoplankton 
243 assemblages in Lichi Mélange matrix are similar to those of nearby Plio-Pleistocene Fanshuliao and Paliwan

244 formations (< 4 Ma), and that exotic sedimentary blocks yield older fossils $(\sim 18$ to $5.6 \mathrm{Ma})$ consistent with 245 an olistostromal interpretation (Chi et al., 1981; Barrier and Muller, 1984; Li, 1984).

However, the sedimentary hypothesis also faces challenges: (1) coherent portions of the "Lichi Formation" are similar to the Fanshuliao and Paliwan formations, creating ambiguities in the definition of stratigraphic units and boundaries; (2) few depositional contacts have been reported in prior published studies;

(3) distal olistostromal facies that are predicted by this hypothesis have not previously been identified in nearby

Fanshuliao and Paliwan formations to the east (Teng, 1981; Chen, 1991); and (4) because Miocene sedimentary

rocks were not recognized in the eastern part of the Central Range directly to the west, some workers argued there is no source area to supply Miocene-age sedimentary slide blocks and olistoliths (Huang et al., 2018).

Taken together, inconsistent stratigraphic definitions and age interpretations have led to major mélange-like marker beds (pebbly mudstone) in the Fanshuliao and Paliwan formations (Lai and Teng, 2016;

Lai, L.S.-H. et al., 2018), and a late Miocene depositional age for metasedimentary rocks in the eastern part of the Central Range (e.g., Chen, W.-S. et al., 2017; Mesalles et al., 2020), have not yet been considered in this debate. These new findings reveal a need to re-evaluate critical field relationships in the Lichi Mélange, refine its definition, and reassess its stratigraphic context in the southern Coastal Range (Fig. 1B).

\subsection{Nomenclature and definitions used in this paper}

In this study, we adopt modern nongenetic terms of "mélange" and "broken formation" to describe

mappable (at 1:25,000 or smaller scale) chaotic rocks that commonly have "pervasively deformed and fragmented matrix of finer-grained material", with and without inclusion of extra-formational blocks respectively (Hsü, 1968; Silver and Beutner, 1980; Raymond, 1984), which represent products of different forming mechanisms - rock-mixing plus stratal disruption versus only stratal disruption (Harris et al., 1998; 
267 Festa et al., 2012). The terms "olistostrome" and "olistolith", traditionally equivalent to "sedimentary mélange" 268 and "slide blocks" following classic principles of stratigraphic superposition (Abbate et al., 1970), are applied 269 to name sedimentary lithofacies in the Lichi Mélange (Table 1). The term "polygenetic mélange" is used for 270 a mélange body formed through a multistage evolution that involves two or more styles of rock-mixing 271 mechanisms (sedimentary, tectonic, or diapiric), and its primary fabrics have been overprinted (reworked) by 272 later processes (Berkland et al., 1972; Ogata et al., 2019b; Festa et al., 2020).

For the stratigraphic framework, this paper adopts an updated descriptive nomenclature and depositional ages for lithostratigraphic units in the Coastal Range, summarized in Fig. 3. The Tuluanshan Formation (Chen, 1997a; Song and Lo, 2002) is capped by a regional unconformity (Dorsey, 1992) and is overlain by 4-7 km of marine flysch of the Fanshuliao and Paliwan formations (Teng, 1987; Chen, 2009; Lai and Teng, 2016; Lai, L.S.-H. et al., 2018). Due to the difficulty of defining the contact between the Lichi Mélange and flysch units, we classify the products of sedimentary processes (i.e., lithofacies) independent of any existing lithostratigraphic classification scheme (Table 1, see details in Section 4). The Lichi Mélange in this study is defined narrowly as rocks (facies X3, olistostrome) characterized by poorly developed stratification that is broadly parallel to regional bedding (equivalent to the "color bands" in Page and Suppe, 1981) and pervasively "sheared" matrix with extra-formational blocks (i.e., scaly block-in-matrix fabric). Chaotic sedimentary rocks without internal shear fabric or foliation that record soft-sediment deformation and sediment gravity flows (i.e., pebbly mudstones (facies X1), slump beds (facies X2), and other coherent strata (facies F1-F4, Vo)) are included in the Fanshuliao and Paliwan formations. For outsized ( $>10 \mathrm{~m}$ to a few km diameter) fractured blocks regardless of lithology that appear in all sedimentary units, we apply the neutral term "olistolith" (facies X4).

The term "exotic block" is reserved for blocks with lithologies whose source is not present in the which are different from any lithology found in country rocks of the Coastal Range (e.g., well-lithified quartz- 
This is a postprint submitted to the EarthArXiv by Larry Syu-Heng Lai

291 rich sandstone without orogen-derived lithic fragments, ophiolitic rocks (gabbro, serpentinite, granodiorite, 292 etc.), metasandstone) (Liou et al., 1977; Page and Suppe, 1981), in contrast to some blocks originated from 293 nearby intra-formational sources such as turbidite facies F2 (so called "native blocks").

It should be noted that the definition of Lichi Mélange as a lithostratigraphic unit in this study is used in a manner of convenience for assessing the geologic map pattern and observed contact relationships, thus serving as the basis for additional analyses, which is different from the classic usage of the lithological term “mélange." Some chaotic facies in the Fanshuliao and Paliwan formations such as pebbly mudstone (X1) and part of slump bed (X2) can be also considered as "sedimentary mélange (olistostrome)" as conventionally defined (Ogata et al., 2019b) or "small-scale mélanges and broken formations" if they are not mappable at 1:25,000 or smaller scale (e.g., Codegone et al., 2012).

\section{Methods} in road cuts and riverbanks of the southern Coastal Range (Fig. 4). Lithostratigraphic descriptions were executed in selected river sections along three geological transects: (1) Powhua-Shinchang; (2) Luye-Tulan; and (3) Fuli-Chengkung transects (Figs. S1-S14). Among these sections, we compiled existing data for microfossil biostratigraphy and magnetostratigraphy from previous studies (Chang, 1967, 1969; Barrier and 308 Muller, 1984; Chen, 1988b; Huang and Yuan, 1994; Horng and Shea, 1996; Chen, W.-H. et al., 2015, 2017) and manually georeferenced their sample localities on maps in order to project them to our measured sections

(Figs, S3-S9). We also include digitized unpublished calcareous nannoplankton fossil data from Chi et al. 311 (1981) in our analysis (Fig. 3 and Table S3). We also collected fresh mud rock samples for new microfossil 312 analysis in the Lichi Mélange matrix and surrounding sedimentary units from all studied river sections (Figs. 313 S3-S9), with a focus on calcareous nannoplankton data that were relatively limited in previous studies and 314 three additional samples for planktonic foraminifera identifications (the Yungfong (YF) section) (Tables S3- 
315 S4). Additional paleomagnetic drill core samples were collected from strata in coherent continuous sections

316 (Fanshuliao and Paliwan formations), and processed through stepwise thermal demagnetization, alternating-

317 field demagnetization, or a combination of both methods to obtain reliable measurements of primary remanent

318 component of the paleomagnetic declination and inclination at each site (Fig. S17). A “double-tilt correction"

319 was later applied to progressively remove tilting by regional fold plunge and then bedding tilt (Fisher, 1953;

320 Ramsay, 1961) (Table S5). After compiling these magneto-biostratigraphy datasets, we interpreted the

321 depositional ages based primarily on paleomagnetic polarity reversals and the first appearance datum (FAD)

322 for index fossils due to potential fossil reworking (Chi et al., 1981; Chen, 1988b, 2009), whose ages follow

323 recent compilations for the Indo-Pacific region (Anthonissen and Ogg, 2012; Backman et al., 2012; Ogg, 2012;

324 Chuang et al., 2018) (Fig. 3).

325 To understand paleo-basin geometry and facies architecture, we constructed three stratigraphic panels

326 by correlating stratigraphic sections along W-E transects (Powhua-Shinchang, Luye-Tulan, Fuli-Chengkung)

327 and hanging the youngest widespread chronostratigraphic horizons, or datums, such as the first appearance

328 datum (FAD) of microfossils, paleomagnetic reversals, and event marker beds like pebbly mudstone (X1) and

329 tuffaceous turbidites (Vo). The approximate unfolded horizontal distance was calculated using standard

330 geometrical methods (e.g., Ragan, 2009) and mean bedding dip along the transects (Fig. 4).

331 To reconstruct sediment routing pathways and sediment sources, we measured sedimentary structures

332 for paleocurrent (e.g., flute casts, ripple cross-lamination, imbricated gravel clasts) and paleoslope (e.g., axial

333 planes of asymmetric slump folds) directions in each studied section and the Loho and Changpin areas,

334 including data for tuffaceous turbidites (Lai, L.S.-H. et al., 2018). All directional data were restored to paleo-

335 horizontal using a "double-tilt correction". More comprehensive descriptions of our methodologies are 336 included in the Supplementary Materials.

\section{Lithofacies and facies associations}


This is a postprint submitted to the EarthArXiv by Larry Syu-Heng Lai

Nine lithofacies are identified in Plio-Pleistocene sedimentary rocks of the southern Coastal Range

based on their distinctive characteristics and corresponding interpreted sedimentary processes (Table 1). We employ the classification scheme of Raymond (1984), in which categories $\alpha$ to $\delta$ are used to indicate degree of stratal disruption. This scheme was widely applied in previous studies of the Lichi Mélange (e.g., Chang et al., 2001; Chen, W.-H. et al., 2017). Lithofacies are then grouped into three facies associations according to their stratigraphic context, sedimentological affiliations, and contact relationships, and these are used to interpret depositional processes, paleoenvironments, and other rock-forming mechanisms (Table 2).

Facies Association 1 (FA1) consists of submarine flysch deposits spanning a wide range of grain size and sedimentary features comprising most of the Fanshuliao and Paliwan formations. The major facies in this group are mudstone (facies F1), turbidites (F2), thick-bedded sandstone and gritstone (F3), and conglomerate (F4) (Fig. 5A, B, C). Finer-grained facies in this association are the depositional products of cohesionless sediment gravity flows including sand-rich low- to high-density turbidity currents and gravel-rich grain flows

(Table 1). Clasts in this facies association are primarily composed of orogen-derived lithic fragments (e.g., slate, low-grade metasandstone), followed by minor andesite and mafic rocks (e.g., basalt, gabbro). They are interpreted as the deposits of proximal to outer submarine fans with supra-fan lobes and channels that formed derived from submarine canyons that funneled sediment downslope from onshore river sources (Stow and Mayall, 2000).

Facies Association 2 (FA2) includes sedimentary deposits that display a wide range of chaotic textures and internal structures formed by stratal disruption, slumping, sliding, and/or rock-mixing (Table 2). Extraformational clasts (pebble size and larger) in these facies include meta-sandstone, slate, volcanic andesite,

361 rich sandstone (Liou et al., 1977; Page and Suppe, 1981; Chen et al., 2008; Lai, L.S.-H. et al., 2018). Pebbly 362 mudstone (X1) and slump beds (X2) represent ductilely deformed and disrupted sediments in the Fanshuliao 


\section{This is a postprint submitted to the EarthArXiv by Larry Syu-Heng Lai}

363 and Paliwan formations (Fig. 5E, F). These facies locally include outsized, decimeter- to kilometer-scale

364 olistoliths (X4) (Fig. 6A, B) that commonly display small-scale internal brittle fractures and local diapiric

365 mudstone intrusions (Fig. 7C) indicating rapid emplacement in unconsolidated sediment that created local

366 fluid overpressure (Ogata et al., 2019a). These olistoliths are composed of various extra-formational lithologies

367 such as andesite, volcaniclastic sandstone and conglomerate, ophiolitic rocks (gabbro, serpentinite, 368 granodiorite, etc.), limestone, and quartz-rich sandstone (Figs. 6A-E, S1-S12). Olistostrome facies (X3) are 369 characterized by very thick massive beds of disturbed mudstone with indistinct bedding and relatively weak 370 shear fabrics (Fig. 6D-E). Intensive rock dismemberment including characteristic boudinage structures occurs 371 locally within the basal zone of slump beds facies (X2) (Fig. 6F), fitting the definition of "broken formation." 372 Well-developed scaly foliations with connective tightly spaced slickensides, schistosity-cisaillement (S-C) 373 fabrics, and reoriented clasts with extensional structures commonly occur along sheared horizons near the base 374 of the olistostrome (X3) (Figs. 6G, S15B). These basal deformation features in chaotic sedimentary rocks may 375 be the result of gravitational-related shearing during mass movements (Tripsanas et al., 2008; Ogata et al., 376 2014). Detailed field observations reveal depositional successions of chaotic facies (FA2) interpreted as 377 products of submarine mass wasting and flow transformations from slides and slumps to cohesive debris flows 378 that initiated on mud-rich unstable submarine slopes and accumulated at base-of-slope to proximal basin plain 379 environments (Ogata et al., 2012; Festa et al., 2016) (Table 2).

380 Lastly, FA3 consists of tuffaceous turbidites (Vo) (Fig. 5D) that represent distal syn-eruptive 381 volcaniclastic deposits associated with syn-collision volcanism of the Luzon Arc (Yang et al., 1995; Lai, L.S.382 H. et al., 2018).

383 This classification scheme permits interpretation of processes using a modern evidence-based 384 approach that provides an unambiguous basis for defining lithostratigraphic units (Tables 1, 2). The Lichi 385 Mélange in this scheme is restricted to facies that display pervasive shear fabrics: olistostrome (X3) (Fig. 6D, 386 E). In contrast, coherent facies (F1-F4), and mixed facies produced by sediment gravity flows and slumping 
This is a postprint submitted to the EarthArXiv by Larry Syu-Heng Lai

387 (X1, X2) are assigned to the Fanshuliao and Paliwan formations (Fig. 5). Olistoliths (X4) are included in the 388 lithostratigraphic unit of its surrounding facies (Fig. 6A, B, C).

\section{Contact and map relationships}

In our field survey, we first identified the fault zone rocks (i.e., uncompacted cataclasite, fragmented mudstone with pencil cleavage, and fault gouge) of the Tuluanshan fault (Fig. 7), which cuts all lithological units including Lichi Mélange in the southern Coastal Range (Figs. 4, S1-S2). These fault zone rocks display brittle shear fabrics with well-polished slickensides that overprint primary sedimentary fabrics and structures of rocks on both sides of the main fault. This observation confirms that brittle shear fabrics are not diagnostic for differentiating chaotic rocks generated by different mechanisms (cf. Chen, 1997b; Chang et al., 2000), and the "structurally ordered block-in-matrix fabrics" subject to tectonic overprints are restricted to narrow fault-damage zones.

In contrast to identified brittle fault contacts, most contacts between Lichi Mélange and other

sedimentary units are depositional. Eight of the best exposed depositional contacts are documented in Fig. 8, including the classic outcrops reported by Page and Suppe (1981) (their Locality J) (Fig. 8A) and Li (1984)

402 (their site L12) (Fig. 8C). According to stratigraphic younging direction indicated by sharp bases and normally graded Bouma sequences in turbidites (facies F2), the Lichi Mélange is both underlain and overlain by deposits of the Fanshuliao and Paliwan formations, in exposures that reveal clear interbedding relationships. Depositional contacts in Chungye river - A (CYCa) and Yungfong (YF) sections exhibit gradational transitions 407 products (FA2), thus displaying clear conformable lithological transitions that reflect straightforward 408 depositional contact relationships (Figs. 10, S15-S16).

The degree of shearing at depositional contacts varies from none (e.g., Fig. 8A, B, D, H) to high (e.g., 410 Fig. 8F). None of the sheared contacts coincides with post-diagenetic brittle fault gauge, cataclasite, or pencil 


\section{This is a postprint submitted to the EarthArXiv by Larry Syu-Heng Lai}

411 cleavage, making them easily distinguished from brittle fault zones of the Tuluanshan fault (Fig. 7) and

412 Wushinshih fault (Lai and Teng, 2016). There is no evidence of shearing at the depositional contacts between

413 Lichi Mélange and Fanshuliao Formation near the headwaters of Mukeng river (MKC) section (Figs. 4, 8C,

414 D, S2), which previous workers speculated is the southern extent of the Tuluanshan fault (e.g., Chen, 1997b;

415 Chang et al., 2000; Huang et al., 2018). Similarly, the well exposed depositional contact at Chunchie river 416 (CC), Chiaolai river (CLC), and Juchiang river (JCC) sections around Fukang area (Page and Suppe, 1981;

417 Lin et al., 2008) clearly refute a previously hypothesized east-vergent thrust at that locality (e.g., Chang et al., 418 2001; Chen, W.-H. et al., 2017; Huang et al., 2018) (Fig. 8A).

419 Some studies map a "Yungfong fault" at the contact between Lichi Mélange and Fanshuliao 420 Formation in the Yungfong (YF) section (Figs. 4, S2), with variously proposed vergence directions (west421 vergent or east-vergent) (Lo et al., 1993; Chen, 1997b; Chang et al., 2000). Soft-sediment extension features 422 (boudinage) are commonly observed in the Lichi Mélange (i.e., olistostrome (X3)). Scaly foliation near the 423 basal sheared contact has an attitude identical to regional bedding dipping toward west (Fig. 8G), and it 424 correlates laterally to another exposure $0.6 \mathrm{~km}$ to the north where an unambiguous depositional contact is 425 reported (Hsu, 1956; Barrier and Muller, 1984) (Figs. 8H, S16). The sense of shear measured along this 426 localized sheared horizon seems to be consistent with the orientation of regional tectonic stress field (Chen, 427 1997b; Chang et al., 2000), but is also consistent with reconstructed paleoslope directions after bedding 428 corrections, suggesting an alternative explanation of gravity-driven sliding and basal shear (see Section 7.1). 429 These relations suggest that localized shear fabrics near the southern contact represent localized shears 430 produced by mass movement at the base of thick olistostrome beds. The YF section appears to be a continuous 431 succession, an interpretation supported by internal consistency among index microfossils (see Section 6.1).

432 Based on careful assessment of contact relationships, our geological map reveals common pinch-out 433 of the Lichi Mélange with lateral and vertical facies transitions to pebbly mudstone beds (X1) of the Fanshuliao 434 and Paliwan formations (Figs. 4, S1-S2), thus confirming their interbedding relationship. The Lichi Mélange 
435 is primarily preserved in the western part of the Coastal Range, except in the Fukang area where thick Lichi

436 Mélange extends to the east and southeast where it is exposed along the modern coastline (Fig. 4). The internal

437 stratification and shear fabrics of the Lichi Mélange broadly coincide with regional bedding trends (Page and

438 Suppe, 1981). We also observe random fabric orientation, particularly around Fukang area, and locally 439 preserved onlap onto channel margins (Fig. 8E), revealing a map pattern typical of large-scale sedimentary 440 mélange (Festa et al., 2019). Lichi Mélange and other units in this area were reworked together by post441 depositional tectonic deformation (cross-cutting thrust faults and folds) (Figs. 4, 7), and therefore the Lichi 442 Mélange can be considered as a "polygenetic mélange."

444 6. Basin-fill stratigraphy of the southern Coastal Range

$445 \quad 6.1$ Age of sedimentary units and unconformities in the southern Coastal Range

446 The sedimentary fill of the southern Coastal Range basin is dominated by Plio-Pleistocene deep447 marine orogen-derived deposits that formed by gravity-driven processes (Lichi Mélange, Fanshuliao and 448 Paliwan formations). These deposits overlie an eastward younging regional unconformity on top of Miocene 449 Shihmen Volcanic Breccia and older Shihtiping Tuff of the Tuluanshan Formation (Fig. 3).

450 Our compilation of age data shows that the same group of youngest index microfossils are present in 451 the matrix of Lichi Mélange and interbedded Fanshuliao and Paliwan formations (Figs. 9, 10, S3-S14). 452 Microfossils whose last-appearance ages are older than the first appearance datum (FAD) of younger ones 453 repeatedly appear in both Lichi Mélange and interbedded units, indicating persistent fossil reworking that 454 limits the reliability of the Last Appearance Datum (LAD) for interpretations of depositional age. Planktonic 455 foraminifera Globorotalia crassaformis (FAD $4.31 \mathrm{Ma}$ ), Globorotalia tosaensis (FAD 3.35 Ma) and 456 calcareous nannoplankton Pseudoemiliania lacunosa (FAD 3.82 Ma) are present in the oldest strata which are 457 exposed in the west, including Mukeng river (MKC), Chungye river (CYC), and Yungfong (YF) sections 458 (Chang, 1967; Barrier and Muller, 1984; Chen, W.-H. et al., 2017) (Figs. 10, S3-S7, S11-S13). At the southeast 
This is a postprint submitted to the EarthArXiv by Larry Syu-Heng Lai

459 end of the Coastal Range (Fukang area) (Figs. 4, S1), calcareous nannoplankton P. lacunosa (FAD 3.82 Ma) 460 and trace Gephyrocapsa oceanica (FAD 1.70 Ma) are present in Lichi Mélange in the Chunchie (CC), Chiaolai 461 river (CLC), and Moon World (MW) sections (Chi et al., 1981; Chen, W.-H. et al., 2017). Large Gephyrocapsa 462 spp. (FAD 1.57 Ma) appears near the top of the underlying Paliwan Formation (Figs. 10C, 11, S5-S6, S12). 463 Although older (Miocene) calcareous nannoplanktons Reticulofenestra pseudoumbilicus (medium and large), 464 Sphenolithus abies, and Discoaster spp. are abundant in the matrix of the Lichi Mélange in this area, the clear 465 evidence for an unsheared depositional contact with stratigraphic superposition (Fig. 8A) and common 466 olistostromal features (Fig. 6D) indicate that the Miocene fossils are reworked from older sediments (Fig. 11). 467 Thus, the whole sedimentary sequence in the southern Coastal Range was deposited between ca. 4 and $1 \mathrm{Ma}$, 468 and the depositional age of the Lichi Mélange is similar to that of interbedded Fanshuliao and Paliwan 469 formations.

The Kangkou Limestone is only preserved at the base of the Sanshian river (SSS), Shingang river 471 (SGS), and Babian river (BBS) sections (Figs. 4, S8, S9). In this area, it contains planktonic foraminifera $G r$. 472 crassaformis (FAD $4.31 \mathrm{Ma}$ ) at the base and abundant Gr. tosaensis (FAD $3.35 \mathrm{Ma}$ ) and Dentoglobigerina 473 altispira (LAD 3.05 Ma) near the top (Fig. S14), suggestive of a depositional age range between 4.31 and 3.05 474 Ma (Huang and Yuan, 1994). Huang and Yuan (1994) interpreted that the top of the Kangkou Limestone may 475 be younger based on a single, uncertainly identified specimen of Globorotalia truncatulinoides (FAD 2.00 Ma) 476 (Sample \#26 in their Table 4). This tentative age assignment is not considered in our compilation because it 477 could not be verified. The Biehchi Epiclastic Unit is exposed at the base of the Bieh river (BC) section and 478 was deposited at ca. 4.2-3.8 Ma based on the presence of planktonic foraminifera Gr. crassaformis (FAD 4.31 479 Ma) (Chang, 1969), calcareous nannoplankton P. lacunosa (FAD 3.82 Ma) (Barrier and Muller, 1984), and 480 the youngest peak U-Pb age ( 4.2 Ma) of detrital zircon (Chen, T.-W. et al., 2015). The age distribution of 481 these two intermittent units partially overlaps that of the Lichi Mélange and lower Fanshuliao Formation, and 
This is a postprint submitted to the EarthArXiv by Larry Syu-Heng Lai

482 appears to be a discontinuous record of the $\sim 2$ Myr transition from the youngest stages of arc volcanism to 483 sedimentary basin formation during collisional orogenesis (Dorsey, 1992).

6.2 Type sections and marker beds of the Fanshuliao and Paliwan formations

The Madagida river (MDJ) and Bieh river - A (BCa) sections are widely accepted as stratotypes for the Fanshuliao and Paliwan formations in the southern Coastal Range (Chen, 2009; Huang et al., 2018) (Fig.

9). Widespread layers of pebbly mudstone (Pm1 to Pm7, facies X1) and tuffaceous turbidites (Tp1 to Tp14, facies Vo) provide useful marker beds that allow us to map and correlate these deposits (Lai and Teng, 2016; Lai, L.S.-H. et al., 2018). In this study, we discovered five more tuffaceous turbidites (Tf1 to Tf5) in the Fanshuliao Formation (Fig. 3). The Paliwan Formation in the MDJ section was previously dated between ca.

2.15 to 1.5 Ma (Horng and Shea, 1996). In this study we refine the age interpretation with revised placement of the first occurrences of G. oceanica (FAD 1.70 Ma) and large Gephyrocapsa spp. (FAD 1.57 Ma) in this section (Fig.9A). The proposed age of the Fanshuliao Formation in the southern Coastal Range varies from 4.94-3.35 Ma (Lee and Chi, 1990; Chen, 2009) to 3.35-2.15 Ma (Horng and Shea, 1996; Lai and Teng, 2016). Based on compilation of previous and new data with lithostratigraphic correlations, the lower Formation corresponds to the lower Matuyama Chron (C2r.2r, 2.59-2.14 Ma) (Fig. 9B). This revised age interpretation is supported by the presence of planktonic foraminifera Gr. tosaensis (FAD $3.35 \mathrm{Ma}$ ) near the bottom of the section (site 222 in Chang, 1969) (Figs. S7, S13B).

Pebbly mudstone and tuffaceous turbidite marker beds have unique sedimentary textures and clast compositions that permit regional correlation. These marker beds are interpreted to record distinct geological events such as seismicity-triggered submarine debris flows and volcanic eruptions (Chen et al., 2008; Lai, L.S.H. et al., 2018). This allows us to tune their ages using our updated high-resolution magneto-biostratigraphy, 
This is a postprint submitted to the EarthArXiv by Larry Syu-Heng Lai

506 and we use the marker beds as age anchors for other sections based on detailed geologic mapping and 507 lithostratigraphic correlation. For example, pebbly mudstone beds Pm2, Pm3, and Pm5 were deposited near 508 the Gauss-Matuyama boundary (2.59 Ma), the onset of Pulleniatina spp. left coiling event 5 (2.15 Ma), and

509 the top of the Olduvai normal polarity event (C2n, 1.80 Ma), respectively. Tuffaceous turbidites Tp7-Tp14 510 formed between the FAD of large Gephyrocapsa spp. (1.57 Ma) and onset of small Gephyrocapsa spp. acme 511 zone (1.23 Ma), consistent with ages determined by apatite fission tracks (1.5 $\pm 0.1 \mathrm{Ma})$ and $\mathrm{U}-\mathrm{Pb}$ zircon dating 512 (1.6 $\pm 0.1 \mathrm{Ma}$ ) on equivalent beds (Yang et al., 1995; Chen, T.-W. et al., 2015). The tuffaceous turbidites Tp3513 Tp4 and pebbly mudstone Pm4 formed around the base of the Olduvai event ( 1.95 Ma), and the tuffaceous 514 turbidites Tf1-Tf2 and pebbly mudstone Pm1 form near the base of C2An.1n event in Gauss Chron ( 3.04 $515 \mathrm{Ma})$.

\subsection{Stratal architecture of the southern Coastal Range}

Using correlations summarized above and restored distances between stratigraphic sections, we constructed 2D west-east facies panels that reveal the original paleo-basin geometry along three studied stratigraphic transects (Figs. 12, 13). The panels show that sedimentary strata of the Fanshuliao and Paliwan

521 formations and Lichi Mélange onlap onto a basin-wide basal unconformity on top of the Tuluanshan Formation 522 (arc volcanic basement). The basal unconformity has a restored gentle west dip $\left(\leq 6-7^{\circ}\right)$ and defines an 523 asymmetric basin low that corresponds to maximum stratigraphic thicknesses near the orogenic front (Dorsey,

1992; Chen, 2009). All members of the Fanshuliao and Paliwan formations thin consistently to the east.

The reconstructed stratigraphic architecture of eastward thinning and onlap in Plio-Pleistocene orogenderived deposits of the southern Coastal Range is unlike the arc-ward thickening stratal pattern that is typically observed in forearc basins (Noda, 2016, 2018). The observations of paleo-basin geometry and evidence for 
This is a postprint submitted to the EarthArXiv by Larry Syu-Heng Lai

530 There is no evidence for a large local bathymetric low to support a backarc basin interpretation (cf. Chen, 531 1988a, 1997a; Song and Lo, 2002) or pull-apart intra-arc basin (cf. Huang et al., 1995, 2006; Chen, W .-H. et 532 al., 2015). Instead, the stratal pattern is best explained as the basin fill of a flexural foredeep basin where 533 deposits thicken toward the orogen that supplied sediment to the basin (DeCelles and Giles, 1996; Sinclair and 534 Naylor, 2012). This interpretation is consistent with the predictions of a syn-collisional retrowedge basin model 535 proposed in other studies (e.g., Dorsey and Lundberg, 1988; Lundberg and Dorsey, 1988; Malavieille et al., 536 2016; Chen et al., 2019). (See details in Section 8.2)

\section{Paleoslope and paleocurrent data}

\subsection{Paleoslope orientations}

Paleoslopes determined from vergence direction of asymmetric slump folds (facies X2) show

541 prevailing east to southeast slump directions in modern coordinates (Fig. 14A). Our results are consistent with 542 previously published data in the Luye region (Page and Suppe, 1981) that indicate a regional east to southeast543 dipping paleoslope in the southern Coastal Range. Structural and bedding-corrected striae measured at the 544 basal depositional contact of Lichi Mélange in YF section (site \#5-6 in figure 7 of Chang et al., 2000) (Fig. 545 8G) and base of a thick exotic sandstone block in JCC section (site \#1-2 in figure 8 of Chang et al., 2001) 546 (Figs. S5, S12B) indicate shear directions consistent with local paleoslope indicators, suggesting that they 547 originated by the similar mass-wasting processes (Fig. 14A). After correcting for $30^{\circ} \pm 10^{\circ}$ clockwise block 548 rotation based on paleomagnetic fabrics (Lee et al., 1990), our results imply a north-striking, east-dipping steep 549 slope at the tectonically controlled western basin margin. This slope was the site of common submarine mass 550 wasting events that generated the Lichi Mélange and associated submarine debris flows (Page and Suppe, 1981; 551 Dorsey and Lundberg, 1988). Minor westward paleoslope directions near the base of the BCa section are 552 interpreted to represent local structural complexities, and do not record a regional-scale west-dipping slope on 553 the western flank of a volcanic arc massif (cf. Huang et al., 1995; Chen, 1997a; Song and Lo, 2002). 
This is a postprint submitted to the EarthArXiv by Larry Syu-Heng Lai

\subsection{Paleocurrent directions}

Paleocurrent directions exhibit temporal and spatial variations among different lithofacies (Fig. 14B).

In orogen-derived turbidites and other cohesionless sediment gravity flow facies (F2-F4), paleotransport is dominantly toward the south in modern coordinates, with increasing indicators of southeastward transport in the southern region. We observe an up-section increase of southeast- transport directions in the younger Paliwan Formation, which is mainly preserved in the eastern part of the basin. Pebbly mudstone (facies X1)

561 shows a dominant paleocurrent toward the southeast (in modern coordinates), consistent with paleoslope 562 directions measured in slump bed (facies X2) nearby (Fig. 14A). In contrast, tuffaceous turbidites (facies Vo) 563 have diverse paleocurrent directions with a relatively stronger components of westward to southwestward 564 paleoflow directions.

After correcting for $30^{\circ} \pm 10^{\circ}$ clockwise block rotation in the Coastal Range rocks (Lee et al., 1990),

we use paleoslope and paleo transport indicators to interpret the location of source areas and sediment-routing pathways for each facies association. The main source of facies association FA1 (facies F2-F4), which formed in a submarine fan system (Table 2), was located northwest of the basin (Teng, 1982; Chen, 1997a). The upsection increase in east-directed paleocurrents implies increased input from the west, which we interpret as a response to eastward migration and basinward advance of the Taiwan collisional orogenic front. Consistent east- to southeast-directed directions of paleocurrent in FA1 and paleoslope in pebbly mudstone (X1) and slump beds (X2) reveal a north-trending, east-dipping submarine slope at the steep unstable western basin margin. This shows that the eastern retrowedge of the Taiwan orogen was the main source of mass-transport deposits in facies association FA2. Syn-eruptive tuffaceous turbidites (FA4) display spatially variable paleocurrent directions with a dominant mode to the west and southwest (Fig. 14B). These turbidites were derived from an active volcanic source east of the basin, not the volcanic island of Lutao located southeast of 
This is a postprint submitted to the EarthArXiv by Larry Syu-Heng Lai

578 eastern source is supported by a westward decrease in thickness of the tuffaceous turbidites (Lai, L.S.-H. et al., 579 2018).

\section{Discussion}

\subsection{Paleogeography and depositional setting}

Stratigraphic panels in the southern Coastal Range reveal an important pattern of lateral facies change in which western sections contain abundant olistostromal facies (association FA2), and age-equivalent sections beds (X2), olistostromes (X3), and olistoliths (X4) are more abundant in the west and pass laterally into distal facies with pebbly mudstone beds (X1) in the east. This facies architecture records downslope disintegration of mass flows during transformation from slides, slumps, and blocky flows to cohesive debris flows to highdensity turbidity currents (Nemec, 1990; Ogata et al., 2012; Festa et al., 2016) (Fig. 15B), consistent with measured dominant eastward paleoslope directions (Fig. 14A). These facies associations formed by submarine 591 slumping and deposition by sediment gravity flows in deep-water slope to submarine fan and basin plain environments (Fig. 15A). The depositional setting was subject to frequent deliveries of orogen-derived sediment that was routed into the basin by a combination of widespread slope failures and gravity-driven transport funneled through submarine canyons (Stow and Mayall, 2000). volcanism during 4-1 Ma deposition of the orogen-derived sedimentary sequence (Lai, Y.-M. et al., 2018;

597 Song and Tang, 2019) (Figs. 12, 13, 15A). The tuffaceous turbidites were derived from volcanoes located east 598 to northeast of the basin (Lai, L.S.-H. et al., 2018) (Fig. 14B), and thus are distinct and different than the 599 magmatic events (>16-14 Ma and 10-6 Ma) recorded in the underlying Tuluanshan Formation below the 600 basal unconformity (Fig. 3). These results are consistent with the presence of north-trending volcanic arc main 601 body identified in the offshore directly east of Taiwan based on well-defined magnetic (Shyu et al., 1996; 
602 Hsieh et al., 2014) and gravity anomalies (Doo et al., 2018). We infer that the offshore volcanoes have

603 subsequently subsided below sea level and are now being deformed in an active offshore imbricate thrust belt 604 (Hsieh et al., 2020).

Based on facies interpretations above, we conclude that strata of the southern Coastal Range accumulated in a syn-orogenic, syn-collisional marine foredeep basin directly east of a steep orogenic front that formed the tectonically active western margin of the basin (Fig. 15). Active volcanoes east of the basin delivered distal tuffaceous turbidites during this time ( 4-1 Ma), suggesting the eruptive centers shifted to the

Plio-Pleistocene volcanoes are distinctly younger than the $\sim 15-6$ Ma volcanic arc and forearc environments 611 recorded in the underlying Tuluanshan Formation, and may be related to a "double island arc" interpretation 612 proposed by Yang et al. (1996).

\subsection{Retro-foredeep basinal system in the Luzon forearc}

Results of our geologic mapping and basin reconstruction reveal that the modern topography of the Coastal Range is controlled by tightly folded and faulted rocks of a marine foredeep basin that formed on the regional thrust faults and related anticlinal culminations (Figs. 2B, 16A) (e.g., Dorsey, 1988; Lundberg and

619 Dorsey, 1988; Chen et al., 2019). This conclusion is a departure from previous interpretations that high topographic ridges in the Coastal Range represent an inherited configuration of relatively undeformed volcanic

621 islands and surrounding forearc, intra-arc, and backarc basins (Figs. 2A, 16B) (e.g., Chen, 1988a; Teng et al., 622 1988; Huang et al., 1995).

Data presented above provide evidence for east-dipping paleoslopes and olistostromal facies in the 
This is a postprint submitted to the EarthArXiv by Larry Syu-Heng Lai

626 filling style of typical forearc basins (Noda, 2016, 2018), it is similar to the architecture of the modern North

627 Luzon Trough as seen in offshore seismic reflection studies south of Taiwan (e.g., Lundberg et al., 1997;

628 Hirtzel et al., 2009; Chi et al., 2014). This similarity suggests that the eastward-onlapping pattern of Plio-

629 Pleistocene orogen-derived deposits in the Coastal Range may reflect inherited, pre-collisional forearc basin

630 bathymetry. It is also not certain that the east-dipping paleoslope at the west margin of the 4-1 Ma Coastal

631 Range basin was controlled by east-vergent thrusts, as proposed by previous workers (e.g., Suppe and Liou,

632 1979; Page and Suppe, 1981; Lundberg and Dorsey, 1990) and this study (Figs. 15A, 16), considering that the

633 west margin of the modern North Luzon Trough does not show consistent east-vergent thrust structures (Fig.

634 1).

Despite these ambiguities, several observations suggest that the modern setting is not an exact analog

for the past. First, the entire Coastal Range basin subsided rapidly below sea level until $\sim 1 \mathrm{Ma}$, as indicated by

the youngest depositional age of thick marine deposits in the north-central Coastal Range (Lee, 1992; Huang

et al., 2018). This requires a major tectonic reorganization that abruptly ended subsidence and initiated uplift,

precluding gradual southward propagation of the collision (see also Lee et al., 2015; Hsu et al., 2016). Second,

it appears the kinematic style at the east margin of the Taiwan collisional orogen may have become more

transpressional in the past ca. 1 Myr during tectonic reorganization (see section 8.4 ). Third, the traditional

642 forearc basin model cannot explain the observed sudden change in depositional age and benthic foraminiferal

643 assemblages at the basal contact of SSS, SGS, and BBS sections (Figs. 13, S14A-B). In these sections the

644 basal erosional unconformity records an age gap of $\sim 6-4 \mathrm{Myr}$ and is capped by the shallow marine Kangkou

645 Limestone which is directly overlain by deep-water flysch (facies F1 and F2) (Huang and Yuan, 1994). These

646 stratigraphic relations imply a dynamic history of vertical crustal motions comprising regional slow uplift and

647 erosion of forearc volcanic basement (Tuluanshan Formation), deposition of shallow-water limestone on the

648 eroded basement, then rapid subsidence to deep water during initiation of the collisional basin (Dorsey, 1992).

649 The vertical crustal motions have previously been interpreted as a localized intra-arc pull-part mechanism 
650 (Huang et al., 1995), but there is no field evidence for large-scale normal faults that postdate deposition of the 651 Kangkou Limestone and predate the Paliwan Formation in the Coastal Range (Barrier and Angelier, 1986; Lin 652 et al., 1999).

We therefore postulate that the asymmetric westward-deepening basin geometry represents a 654 deflection profile produced by lithospheric flexure in response to tectonic loading in the Taiwan collisional 655 orogen to the west (Fig. 16A). This is consistent with rapid sediment accumulation rates in the Coastal Range $656\left(\geq 1-7 \mathrm{~mm} \mathrm{yr}^{-1}\right)$ that record rapid subsidence east of the growing Taiwan collisional orogen in response to rapid 657 thrust-loading in the orogenic thrust belt during deposition (Lundberg and Dorsey, 1988). Within this 658 framework, the basal unconformity between the Tuluanshan Formation and overlying orogen-derived 659 sediments is interpreted as a result of regional uplift and erosion on a broad flexural forebulge (Dorsey, 1992) 660 (Fig. 3). The Kangkou Limestone and Biehchi Epiclastic Unit formed during development of the unconformity 661 ( 6-4 Ma), and they represent local thin discontinuous deposits that accumulated intermittently on the flexural 662 forebulge. These relationships suggest rapid subsidence in response to an eastward migrating wave of flexural 663 depression that is a common aspect of foreland basin evolution (DeCelles and Giles, 1996; DeCelles, 2012). This hypothesis is consistent with the observed eastward progradation of coarse-sediment facies 665 including mass-wasting deposits (X1 and X3) and channelized gravelly sediment gravity-flow deposits (F3 666 and F4), which are best explained as the result of basinward migration of the depocenter in response to an 667 eastward advancing submarine slope at the retrowedge orogenic front, likely caused by a series of east-vergent 668 thrusts (Figs. 15A, 16A). This pattern represents a marine analog to migrating coarse-sediment facies that are commonly interpreted as a response to a migrating flexural wave in terrestrial foreland basins (Heller et al., 670 1988; Sinclair, 2012; Dubille and Lavé, 2015).

671 Lithofacies of the Tuluanshan Formation beneath the basal unconformity (Fig. 3) make up a sequence 672 of volcanic and volcaniclastic rocks that record underwater to subaerial eruptions within and on the flanks of 673 late Miocene ( 15-6 Ma) subduction-related arc volcanoes (Chen, 1997a; Song and Lo, 2002; Lai and Song, 
674 2013). This suggests that the Plio-Pleistocene retro-foredeep basin of the Coastal Range formed on top of older, 675 deeply subsided crust of an inactive Luzon Arc, similar to the modern retro-foredeep in the North Luzon 676 Trough offshore of southeastern Taiwan (Fig. 1A). In the modern southeast offshore region, a unique 677 collisional foredeep basin is forming where the forearc is closing due to the transition from intra-oceanic 678 subduction to a mature arc-continent collision (e.g., Lundberg et al., 1997; Hirtzel et al., 2009).

\subsection{Genesis and distribution of the Lichi Mélange}

All published studies agree that the modern expression and distribution of the Lichi Mélange are influenced by tectonic shearing related to faults in the western Coastal Range that have been active in the past ca. 1 Myr (e.g., Page and Suppe, 1981; Chang et al., 2000). However, there is a considerable debate over the question of whether sedimentary processes (e.g., sliding and slumping) were involved in formation of this mélange (Teng, 1981; Chen, 1997b; Huang et al., 2018). This study confirms the ubiquitous presence of depositional contacts and interbedding between Lichi Mélange and Plio-Pleistocene orogen-derived flysch facies of the Fanshuliao and Paliwan formations (Figs. 8, 10). Young ( 4-1 Ma) microfossils coexist among these sedimentary units in the southern Coastal Range (Fig. 11), providing an important new constraint on this question. Our data show that the Lichi Mélange was generated by olistostromal and mass-wasting processes

(Fig. 15). We also observe evidence of overprinting tectonic shear fabrics and fault-zone breccias produced by 691 post-depositional, cross-cutting, west-vergent thrust faults including the Tuluanshan fault (Figs. 4, 8). This late-stage structural disturbance is currently active along the strands of the active Longitudinal Valley fault

693 (Angelier et al., 2000; Lee et al., 2006). The structural fabrics related to young deformation are mainly 694 restricted to brittle damage zones within and adjacent to the faults, and they are volumetrically minor compared 695 to widespread sedimentary features and depositional contacts that are commonly observed in the Lichi 696 Mélange (Page and Suppe, 1981; Barrier and Muller, 1984). 
This is a postprint submitted to the EarthArXiv by Larry Syu-Heng Lai

Based on evidence presented above, we propose a polygenetic model for evolution of the Lichi Mélange in eastern Taiwan (Fig. 16A). During the growth of orogenic topography between $\sim 6$ and 1 Ma, eastward propagating thrust faults drove basinward migration of a steep submarine slope at the advancing retrowedge front of the collisional orogen (e.g., Malavieille et al., 2021) (Fig. 16A-1, A-2). Thrust-controlled slope oversteepening resulted in slope failures, slides, and slumps that produced olistostrome deposits at the western margin of a syn-orogenic marine foredeep basin formed on older inactive arc and forearc crust (Fig. 15A). During the advance of the orogenic thrust front, older olistostromes and associated sediments may be reworked into the frontal slope to produce new olistostromes, thus forming an "olistostromal carpet" (see Festa et al., 2010 and references therein). Later, the olistostrome deposits were overprinted by post-depositional tectonic fault zones associated with the Tuluanshan and Longitudinal Valley faults (Fig. 16A-3). The young, post-1 Ma stage of active deformation and rapid uplift inverted the foredeep basin along west-vergent thrusts in the Coastal Range (Lundberg and Dorsey, 1990), rapidly constructed steep rugged topography of the modern Coastal Range, and overprinted the Lichi Mélange to form a polygenetic mélange.

Our interpretation for the Lichi Mélange contrasts with a popular model proposed in prior studies, in which the Lichi Mélange solely formed by tectonic shearing of older sedimentary rocks in an east-vergent then west-vergent mega-thrust zone as a result of large-scale tectonic shortening in the forearc region (e.g., Chen, 1997b; Chang et al., 2001; Huang et al., 2018) (Fig. 16B). New constraints on the age, contacts, map relations, interbedding, and sedimentary facies associations (this study) contradict the "tectonic-only" mélange model, and clearly require emplacement by submarine mass wasting. Some workers suggest that preservation of the Lichi Mélange in the western belt of the southern Coastal Range indicates that it formed as a tectonic mélange produced entirely by fault zone deformation (Teng, 1981; Chen, 1991; Huang et al., 2018). However, the affinity of mélange to fault zones only suggests the likelihood of structural overprints, and does not provide evidence for its origin (Festa et al., 2019; Raymond, 2019; Wakabayashi, 2019). In fact, abundant olistostromal facies such as slump beds (X2), pebbly mudstone (X1), and olistoliths (X4) are also reported close to mapped 
This is a postprint submitted to the EarthArXiv by Larry Syu-Heng Lai

721 patches of Lichi Mélange in the northern Coastal Range (e.g., Dorsey and Lundberg, 1988; Song et al., 1994;

722 Teng et al., 2002), suggesting that deposits associated with the sedimentary mélange are common in the 723 northern Coastal Range as well.

The extent to which tectonic deformation has been absorbed in the present form of the Lichi Mélange

remains unclear. It is plausible that post-depositional structures (both pre-1 Ma east-vergent thrusts and post-

1 Ma west-vergent thrusts) influenced some of the shear surfaces formed by preceding olistostromal processes

(Fig. 16A-2, A-3). Further meso-scale and microscopic studies of shear fabrics in the mélange matrix are needed to address this question.

\subsection{Crustal shortening and tectonic recycling at the suture of an arc-continent collision}

Because the Lichi Mélange formed primarily by sedimentary mass-wasting processes, the belt of rocks shortening associated with accretion of the Luzon Arc (e.g., Teng, 1987; Chen, 1997b; Chang et al., 2001; Huang et al., 2008). Tectonic horizontal shortening within the Coastal Range is primarily taken up by structures of the west-vergent fold-and-thrust belt that initiated ca. $1 \mathrm{Ma}$ and post-date deposition in the Coastal Range foredeep basin (Chi et al., 1981; Dorsey, 1992). In addition, convergence on the oblique west-vergent Longitudinal Valley fault, and east-vergent thrust belt offshore of eastern Taiwan (e.g., Huang et al., 2010; Hsieh et al., 2020), suggests that the Coastal Range is an active doubly-vergent transpressional wedge within the active collisional suture between the Eurasian and Philippine Sea plates (e.g., Malavieille et al., 2016; Thomas et al., 2014) (Figs. 16A). Similar doubly-vergent wedge structures have been reported in the northern 741 Coastal Range (e.g., Yen et al., 2018), directly offshore to the east (Hsieh et al., 2020), and the Huatung Ridge 742 in southern offshore (e.g., Huang et al., 2000; Hirtzel et al., 2009; Chi et al., 2014) (Figs. 1A). 


\section{This is a postprint submitted to the EarthArXiv by Larry Syu-Heng Lai}

745 volcaniclastic sandstone, limestone, ophiolitic rocks (gabbro, serpentinite, granodiorite), low-grade

746 metasandstones, slate fragments, and Miocene quartz-rich sandstones that represent fragments of the Eurasian

747 and Philippine Sea plates. This observation, combined with widespread evidence for east- and southeast-

748 dipping paleoslopes, indicates that all of these rock types were exposed and deformed in thrust sheets in the 749 eastern retro-wedge of the Taiwan collisional orogen (Fig. 16A). We propose that many of these rock 750 lithologies represent shallow-crustal equivalents of high-P greenschist to blueschist grade metamorphic rocks 751 in the Yuli Belt, which occupies the easternmost belt of the metamorphic Central Range belt directly west of 752 the Coastal Range (Figs. 1, 16A). The Yuli Belt was recently recognized as a metamorphosed late-Miocene ( 753 6-9 Ma) mélange (Chen, W.-S. et al., 2017; Mesalles et al., 2020) that contains Miocene mafic and ultramafic 754 fragments of the South China Sea as well as arc-affinity metavolcanic rocks (e.g., Jahn and Liou, 1977; Sun et 755 al., 1998). Unmetamorphosed equivalents of similar aged low-grade meta-sediments (i.e., Eastern Slates) 756 adjacent to the Yuli Belt (Fig. 1A), interpreted as a former forearc basin sequence (e.g., Stanley et al., 1981; 757 Mesalles, 2014), represent the likely source of exotic Miocene sedimentary blocks in the Lichi Mélange (Chi 758 et al., 1981). This idea is supported by the distinctive quartz-rich petrography of exotic sandstone blocks, which 759 closely resembles that of sedimentary rocks now exposed at the south end of the Eastern Slate belt on the 760 Hengchun peninsula (Sung, 1991).

These results suggest that volcanic arc and forearc crustal fragments of the oceanic Philippine Sea plate were tectonically recycled into the eastern retrowedge of the collisional orogen, likely by accretion and/or underplating within a subduction zone or subduction channel complex. This took place during deposition of the Lichi Mélange, prior to final closure of the retro-foredeep basin (Suppe and Liou, 1979; Page and Suppe, 1981; Malavieille et al., 2016). A modern analog may be seen in the Timor arc-continent collision system, where a retro-foredeep basin is currently active in the Banda forearc region and fragments of the Banda Arc

767 crust have already been emplaced in the Bobonaro Mélange in the retrowedge sector of the active Timor 768 collisional orogen (e.g., Harris et al., 1998; Tate et al., 2015). Another comparable example of tectonically 
This is a postprint submitted to the EarthArXiv by Larry Syu-Heng Lai

769 reworked olistostromes that formed in the retrowedge of a collisional orogen is well-documented in the late

770 Cretaceous - Eocene northern Apennine belt in Italy (e.g., Malavieille et al., 2016; Barbero et al., 2020).

During the past ca. 1 Myr, the Lichi Mélange and retro-foredeep strata of the Coastal Range have been

rapidly uplifted, imbricated, and incorporated along with underlying volcanic arc crust into the leading edge

of the modern collisional orogen (Fig. 16A). These rocks are now part of a new, rapidly uplifting emergent mountain range that represents a potential source for a new generation of mélange formation (either tectonic or sedimentary). This large-scale mechanism of arc crustal shortening and tectonic recycling at the oceanpolygenetic mélange in arc-continent collision systems, which play a critical role in the growth of continental lithosphere through time (Clift et al., 2008; Draut and Clift, 2012).

\section{Conclusions}

Our multidisciplinary study confirms a sedimentary origin for the ca. 4-1 Ma Lichi Mélange in the southern Coastal Range of eastern Taiwan. This unit formed by submarine slope failures, slides, slumps, and debris flows that interfinger laterally with a coeval thick (ca. 4-7 km) succession of turbidite-dominated flysch and onlaps eastward onto a regional unconformity that formed by erosion of older, late Miocene volcanic-arc and forearc-basin deposits. Major arc volcanism recorded in the Miocene Tuluanshan Formation ceased prior to the onset of eastward migrating subsidence, which we infer took place in front of the east-vergent retrowedge of the collisional orogen. Minor tuffaceous turbidites in the post-Miocene flysch sequence record input from a different, younger volcanic source that was located offshore to the east during Plio-Pleistocene basin development. Diverse rock types in Lichi Mélange blocks and clasts of associated debris flow deposits indicate 
792 eastern retrowedge belt of the collisional orogen during the 4-1 Ma formation of the Lichi Mélange and 793 associated flysch deposits near the tectonically controlled western margin of the basin.

794 During the past ca. 1 Myr, the Lichi Mélange and retro-foredeep strata of the Coastal Range have been 795 rapidly uplifted, deformed, and incorporated into the ocean-facing margin of the modern collisional orogen 796 along with underlying Miocene volcanic arc crust. The present-day expression of the Lichi Mélange is 797 modified by structural overprints and fault-zone fabrics, but the mélange itself did not form solely by fault798 zone processes. It is a complex association of olistostromes emplaced by large submarine slides and slumps 799 derived from the eastern retrowedge of the Taiwan collisional orogen. These results reveal a dynamic and 800 complicated history of mélange-forming processes in respond to frequent rock mixing and reworking at the 801 oceanic interface of an active arc-continent collision. Similarity between our findings in eastern Taiwan and 802 other polygenetic mélanges associated with retrowedge basins suggests that long-term tectonic recycling 803 associated with crustal shortening may be a common process in retrowedge foredeep basins of active 804 collisional orogens, particularity in (but not limited to) arc-continent collision systems.

\section{Acknowledgements}

We appreciate valuable reviews by Andrea Festa and an anonymous reviewer, and an informal review by John Suppe, which greatly improved this manuscript. We thank Chien-Hao Wang, Kuan-Yu Wang, Ping-

809 Chuan Chen, and Charlie Ogle for field assistance, and Kuo-Hang Chen, Chun-Hung Lin for collecting and 810 processing samples for paleomagnetism and nannofossil analyses. This research was funded by the Geological

811 Society of America (2018 Graduate Student Research Grant) and the Ministry of Science and Technology of 812 Taiwan (MOST 107-2811-M-259-002).

\section{References}

815 Abbate, E., Bortolotti, V., Passerini, P., 1970. Olistostromes and olistoliths. Sedimentary Geology 4, 521-557. 
This is a postprint submitted to the EarthArXiv by Larry Syu-Heng Lai

816 Angelier, J., Chu, H.-T., Lee, J.-C., Hu, J.-C., 2000. Active faulting and earthquake risk: the Chihshang Fault case, 817 Taiwan. Journal of Geodynamics 29, 151-185.

818 Anthonissen, D.E., Ogg, J.G., 2012. Appendix 3 - Cenozoic and Cretaceous biochronology of planktonic 819 foraminifera and calcareous nannofossils. In: Gradstein, F.M., Ogg, J.G., Schmitz, M.D., Ogg, G.M. (Eds.), 820 The Geologic Time Scale 2012. Elsevier, Boston, USA, pp. 1083-1127.

821 Backman, J., Raffi, I., Rio, D., Fornaciari, E., Pälike, H., 2012. Biozonation and biochronology of Miocene through 822 Pleistocene calcareous nannofossils from low and middle latitudes. Newsletters on Stratigraphy 45, 221-244. 823 Barbero, E., Festa, A., Saccani, E., Catanzariti, R., D'Onofrio, R., 2020. Redefinition of the Ligurian Units at the 824 Alps-Apennines junction (NW Italy) and their role in the evolution of the Ligurian accretionary wedge: constraints from mélanges and broken formations. Journal of the Geological Society 177, 562-574.

Barrier, E., Muller, C., 1984. New observations and discussion on the origin and age of the Lichi Mélange. Memoir of the Geological Society of China 6, 303-325.

Barrier, E., Angelier, J., 1986. Active collision in eastern Taiwan: the Coastal Range. Tectonophysics 125, 39-72.

Beyssac, O., Negro, F., Simoes, M., Chan, Y.C., Chen, Y.G., 2008. High-pressure metamorphism in Taiwan: from oceanic subduction to arc-continent collision? Terra Nova 20, 118-125.

Biq, C.C., 1977. The Kenting Mélange and the Manila Trench. Proceedings of the Geological Society of China 20, 119-122.

Buchovecky, E.J., Lundberg, N., 1988. Clay mineralogy of mudstones from the southern Coastal Range, eastern Taiwan: Unroofing of the orogen versus in-situ diagenesis. Acta Geologica Taiwanica: Science Reports of the National Taiwan University 26, 247-261.

Chang, C.-P., Angelier, J., Huang, C.-Y., 2000. Origin and evolution of a melange: the active plate boundary and suture zone of the Longitudinal Valley, Taiwan. Tectonophysics 325, 43-62.

Chang, C.-P., Angelier, J., Huang, C.-Y., Liu, C.-S., 2001. Structural evolution and significance of a melange in a collision belt: the Lichi Melange and the Taiwan arc-continent collision. Geological Magazine 138, 633-651.

Chang, L.S., 1967. A biostratigraphic study of the Tertiary in the Coastal Range, eastern Taiwan, based on smaller foraminifera (I: southern part). Proceedings of the Geological Society of China 10, 64-76. 
This is a postprint submitted to the EarthArXiv by Larry Syu-Heng Lai

842 Chang, L.S., 1969. A biostratigraphic study of the Tertiary in the Coastal Range, eastern Taiwan, based on smaller 843 foraminifera (III: middle part). Proceedings of the Geological Society of China 12, 89-101.

844 Chen, T.-W., Chung, S.-L., Chen, W.-S., 2015. Zircon U-Pb geochronology of the Plio-Pleistocene volcanogenic 845 and orogenic sedimentary rocks from the Coastal Range, eastern Taiwan. EGU General Assembly, 12-17 April, 846 2015, Vienna, Austria. Abstract \#EGU2015-7818-1.

847 Chen, W.-H., Huang, C.-Y., Lin, Y.-J., Zhao, Q., Yan, Y., Chen, D., Zhang, X., Lan, Q., Yu, M., 2015. Depleted 848 deep South China Sea $813 \mathrm{C}$ paleoceanographic events in response to tectonic evolution in Taiwan-Luzon Strait 849 since Middle Miocene. Deep Sea Research Part II: Topical Studies in Oceanography 122, 195-225.

850 Chen, W.-H., Huang, C.-Y., Yan, Y., Dilek, Y., Chen, D., Wang, M.-H., Zhang, X., Lan, Q., Yu, M., 2017. 851 Stratigraphy and provenance of forearc sequences in the Lichi Mélange, Coastal Range: Geological records of 852 the active Taiwan arc-continent collision. Journal of Geophysical Research: Solid Earth 122, 7408-7436.

853 Chen, W.-S., 1988a. Development of deep-sea fan systems in Coastal Range basin, eastern Taiwan. Acta Geologica 854 Taiwanica: Science Reports of the National Taiwan University 26, 37-56.

855 Chen, W.-S., 1988b. Tectonic Evolution of Sedimentary Basins in Coastal Range, Taiwan (Ph.D. thesis). National 856 Taiwan University, Taipei, Taiwan, 344 pp. (in Chinese).

857 Chen, W.-S., 1991. Origin of the Lichi Melange in the Coastal Range, eastern Taiwan. Special Publication of the 858 Central Geological Survey, MOEA 5, 257-266. (in Chinese with English abstract).

859 Chen, W.-S., 1997a. Lithofacies analyses of the arc-related sequence in the Coastal Range, eastern Taiwan. Journal 860 of the Geological Society of China 40,313-338.

861 Chen, W.-S., 1997b. Mesoscopic structures developed in the Lichi melange during arc-continent collision in Taiwan 862 region. Journal of the Geological Society of China 40, 415-434.

863 Chen, W.-S., 2009. Tectonostratigraphic framework and age of the volcanic-arc and collision basins in the Coastal 864 Range, eastern Taiwan. Western Pacific Earth Sciences 9, 67-98 (in Chinese with English abstract).

865 Chen, W.-S., Lin, I.-C., Yen, Y.-C., Yang, C.-C., Chi, C.-Y., Huang, N.-W., Lin, C.-W., Lin, W.-S., Hou, C.-S., 866 Liu, Y.-C., Lin, Y.-H., Shih, T.-S., Lu, S.-T., 2008. Fault segmentation of the Longitudinal Valley Fault in 
This is a postprint submitted to the EarthArXiv by Larry Syu-Heng Lai

867

868

869

870

eastern Taiwan: Evidence from paleoseismic investigations and GPS observations. Special Publication of the Central Geological Survey, MOEA 20, 165-191. (in Chinese with English abstract).

Chen, W.-S., Chung, S.-L., Chou, H.-Y., Zugeerbai, Z., Shao, W.-Y., Lee, Y.-H., 2017. A reinterpretation of the metamorphic Yuli belt: Evidence for a middle-late Miocene accretionary prism in eastern Taiwan. Tectonics 36, 188-206. https://doi.org/10.1002/2016TC004383.

Chen, W.-S., Yeh, J.-J., Syu, S.-J., 2019. Late Cenozoic exhumation and erosion of the Taiwan orogenic belt: New insights from petrographic analysis of foreland basin sediments and thermochronological dating on the metamorphic orogenic wedge. Tectonophysics 750, 56-69.

Chen, W.-S., Yang, C.-Y., Chen, S.-T., Huang, Y.-C., 2020. New insights into Holocene marine terrace development caused by seismic and aseismic faulting in the Coastal Range, eastern Taiwan. Quaternary Science Reviews 240, 106369. https://doi.org/10.1016/j.quascirev.2020.106369.

Chi, W.-C., Chen, L., Liu, C.-S., Brookfield, M., 2014. Development of arc-continent collision mélanges: Linking onshore geological and offshore geophysical observations of the Pliocene Lichi Mélange, southern Taiwan and northern Luzon arc, western Pacific. Tectonophysics 636, 70-82.

Chi, W.-R., Namson, J., Suppe, J., 1981. Stratigraphic record of plate interactions in the Coastal Range of eastern Taiwan. Memoir of the Geological Society of China 4, 155-194.

Chuang, C.-K., Lo, L., Zeeden, C., Chou, Y.-M., Wei, K.-Y., Shen, C.-C., Mii, H.-S., Chang, Y.-P., Tung, Y.-H., 2018. Integrated stratigraphy of ODP Site 1115 (Solomon Sea, southwestern equatorial Pacific) over the past 3.2 Ma. Marine Micropaleontology 144, 25-37.

Clift, P.D., Vannucchi, P., 2004. Controls on tectonic accretion versus erosion in subduction zones: Implications for the origin and recycling of the continental crust. Reviews of Geophysics 42, RG2001. https://doi.org/10.1029/2003RG000127.

Clift, P.D., Lin, A.T.S., Carter, A., Wu, F., Draut, A.E., Lai, T.H., Fei, L.Y., Schouten, H., Teng, L., 2008. Postcollisional collapse in the wake of migrating arc-continent collision in the Ilan Basin, Taiwan. In: Draut, A.E., 
This is a postprint submitted to the EarthArXiv by Larry Syu-Heng Lai

891

Clift, P.D., Scholl, D.W. (Eds.), Formation and Applications of the Sedimentary Record in Arc Collision Zones. The Geological Society of America Special Papers 436, pp. 257-278.

Codegone, G., Festa, A., Dilek, Y., Pini, G.A., 2012. Small-scale polygenetic mélanges in the Ligurian accretionary complex, Northern Apennines, Italy, and the role of shale diapirism in superposed mélange evolution in orogenic belts. Tectonophysics 568-569, 170-184.

Conand, C., Mouthereau, F., Ganne, J., Lin, A.T.-S., Lahfid, A., Daudet, M., Mesalles, L., Giletycz, S., Bonzani, M., 2020. Strain partitioning and exhumation in oblique Taiwan collision: Role of rift architecture and plate kinematics. Tectonics 39, e2019TC005798. https://doi.org/10.1029/2019tc005798.

Cowan, D.S., 1985. Structural styles in Mesozoic and Cenozoic mélanges in the western Cordillera of North America. Geological Society of America Bulletin 96, 451-462.

DeCelles, P.G., 2012. Foreland basin systems revisited: Variations in response to tectonic settings. In: Busby, C., Azor, A. (Eds.), Tectonics of Sedimentary Basins: Recent Advances. Blackwell Publishing Ltd., Oxford, UK, pp. 405-426.

DeCelles, P.G., Giles, K.A., 1996. Foreland basin systems. Basin Research 8, 105-123.

Dilek, Y., Festa, A., Ogawa, Y., Pini, G.A., 2012. Chaos and geodynamics: Mélanges, mélange-forming processes and their significance in the geological record. Tectonophysics 568-569, 1-6.

Doo, W.-B., Lo, C.-L., Hsu, S.-K., Tsai, C.-H., Huang, Y.-S., Wang, H.-F., Chiu, S.-D., Ma, Y.-F., Liang, C.-W., 2018. New gravity anomaly map of Taiwan and its surrounding regions with some tectonic interpretations. Journal of Asian Earth Sciences 154, 93-100.

Dorsey, R.J., 1985. Petrography of Neogene sandstones from the Coastal Range of eastern Taiwan: response to arccontinent collision. Petroleum Geology of Taiwan 21, 187-215.

Dorsey, R.J., 1988. Provenance evolution and unroofing history of a modern arc-continent collision: Evidence from petrography of Plio-Pleistocene sandstones, eastern Taiwan. Journal of Sedimentary Research 58, 208-218.

Dorsey, R.J., 1992. Collapse of the Luzon volcanic arc during onset of arc-continent collision: Evidence from a Miocene-Pliocene unconformity, eastern Taiwan. Tectonics 11, 177-191. 
This is a postprint submitted to the EarthArXiv by Larry Syu-Heng Lai

916 Dorsey, R.J., Lundberg, N., 1988. Lithofacies analysis and basin reconstruction of the Plio-Pleistocene collisional 917 basin, Coastal Range of eastern Taiwan. Acta Geologica Taiwanica Science Reports of the National Taiwan $918 \quad$ University 26, 57-132.

919 Dorsey, R.J., Buchovecky, E.J., Lundberg, N., 1988. Clay mineralogy of Pliocene-Pleistocene mudstones, eastern 920 Taiwan: Combined effects of burial diagenesis and provenance unroofing. Geology 16, 944-947.

921 Draut, A.E., Clift, P.D., 2012. Basins in arc-continental collisions. In: Cathy, B., Antonio, A. (Eds.), Tectonics of 922 Sedimentary Basins: Recent Advances. Blackwell Publishing Ltd., Oxford, UK, pp. 347-368.

923 Draut, A.E., Clift, P.D., 2013. Differential preservation in the geologic record of intraoceanic arc sedimentary and 924 tectonic processes. Earth-Science Reviews 116, 57-84.

925 Dubille, M., Lavé, J., 2015. Rapid grain size coarsening at sandstone/conglomerate transition: similar expression in 926 Himalayan modern rivers and Pliocene molasse deposits. Basin Research 27, 26-42.

927 Ernst, W.G., 1977. Olistostromes and included ophiolitic debris from the Coastal Range of eastern Taiwan. Memoir 928 of the Geological Society of China 2, 97-114.

929 Festa, A., Pini, G.A., Dilek, Y., Codegone, G., 2010. Mélanges and mélange-forming processes: a historical $930 \quad$ overview and new concepts. International Geology Review 52, 1040-1105.

931 Festa, A., Dilek, Y., Pini, G.A., Codegone, G., Ogata, K., 2012. Mechanisms and processes of stratal disruption and 932 mixing in the development of mélanges and broken formations: Redefining and classifying mélanges. 933 Tectonophysics 568-569, 7-24.

934 Festa, A., Ogata, K., Pini, G.A., Dilek, Y., Alonso, J.L., 2016. Origin and significance of olistostromes in the 935 evolution of orogenic belts: A global synthesis. Gondwana Research 39, 180-203.

936 Festa, A., Pini, G.A., Ogata, K., Dilek, Y., 2019. Diagnostic features and field-criteria in recognition of tectonic, 937 sedimentary and diapiric mélanges in orogenic belts and exhumed subduction-accretion complexes. Gondwana $938 \quad$ Research 74, 7-30.

939 Festa, A., Ogata, K., Pini, G.A., 2020. Polygenetic mélanges: a glimpse on tectonic, sedimentary and diapiric 940 recycling in convergent margins. Journal of the Geological Society 177, 551-561. 
This is a postprint submitted to the EarthArXiv by Larry Syu-Heng Lai

941 Fisher, D.M., Willett, S., Yeh, E.-C., Clark, M.B., 2007. Cleavage fronts and fans as reflections of orogen stress 942 and kinematics in Taiwan. Geology 35, 65-68. https://doi.org/10.1130/g22850a.1.

943 Fisher, R.A., 1953. Dispersion on a sphere. Proceedings of the Royal Society of London. Series A. Mathematical $944 \quad$ and Physical Sciences 217, 295-305.

945 Greenly, E., 1919. The Geology of Anglesey: London. Geological Survey of Great Britain. Her Majesty's Stationery $946 \quad$ Office, Richmond, UK, 980 pp.

947 Harris, R.A., Audley-Charles, M.G., 1987. Taiwan and Timor neotectonics: A comparative review. Memoir of the $948 \quad$ Geological Society of China 9, 45-61.

949 Harris, R.A., Sawyer, R.K., Audley-Charles, M.G., 1998. Collisional melange development: Geologic associations 950 of active melange-forming processes with exhumed melange facies in the western Banda orogen, Indonesia. $951 \quad$ Tectonics $17,458-479$.

952 Heller, P.L., Angevine, C.L., Winslow, N.S., Paola, C., 1988. Two-phase stratigraphic model of foreland-basin $953 \quad$ sequences. Geology 16, 501-504.

954 Hirtzel, J., Chi, W.C., Reed, D., Chen, L., Liu, C.S., Lundberg, N., 2009. Destruction of Luzon forearc basin from 955 subduction to Taiwan arc-continent collision. Tectonophysics 479, 43-51.

956 Ho, C.S., 1977. Mélanges in the Neogene sequence of Taiwan. Memoir of the Geological Society of China 2, 8595796.

958 Horng, C.S., Shea, K.S., 1996. Dating of the Plio-Pleistocene rapidly deposited sequence based on integrated 959 magneto-biostratigraphy: a case study of the madagida-chi section, coastal range, eastern Taiwan. Journal of 960 the Geological Society of China 39, 31-58.

961 Hsieh, H.-H., Chen, C.-H., Lin, P.-Y., Yen, H.-Y., 2014. Curie point depth from spectral analysis of magnetic data 962 in Taiwan. Journal of Asian Earth Sciences 90, 26-33.

963 Hsieh, M.-L., Rau, R.-J., 2009. Late Holocene coseismic uplift on the Hua-tung coast, eastern Taiwan: Evidence 964 from mass mortality of intertidal organisms. Tectonophysics 474, 595-609. 
This is a postprint submitted to the EarthArXiv by Larry Syu-Heng Lai

965 Hsieh, Y.-H., Liu, C.-S., Suppe, J., Byrne, T.B., Lallemand, S., 2020. The Chimei submarine canyon and fan: A 966 record of Taiwan arc-continent collision on the rapidly deforming over-riding plate. Tectonics 39, 967 e2020TC006148. https://doi.org/10.1029/2020TC006148.

968 Hsü, K.J., 1968. Principles of mélanges and their bearing on the Franciscan-Knoxville paradox. Geological Society 969 of America Bulletin 79, 1063-1074.

970 Hsü, K.J., 1988. Mélange and the mélange tectonics of Taiwan. Proceedings of the Geological Society of China 31, $971 \quad 87-92$.

972 Hsu, T.L., 1956. Geology of the Coastal Range, eastern Taiwan. Bulletin of the Central Geological Survey of 973 Taiwan 8, 39-63.

974 Hsu, W.-H., Byrne, T.B., Ouimet, W., Lee, Y.-H., Chen, Y.-G., van Soest, M., Hodges, K., 2016. Pleistocene onset 975 of rapid, punctuated exhumation in the eastern Central Range of the Taiwan orogenic belt. Geology 44, 719$976 \quad 722$.

977 Huang, C.-Y., Yuan, P.B., 1994. Stratigraphy of the Kangkou Limestone in the Coastal Range, eastern Taiwan. $978 \quad$ Journal of Geological Society of China 37, 585-605.

979 Huang, C.-Y., Yuan, P.B., Song, S.-R., Lin, C.W., Wang, C.S., Chen, M.T., Shyu, C.T., Karp, B., 1995. Tectonics 980 of short-lived intra-arc basins in the arc-continent collision terrane of the Coastal Range, eastern Taiwan. 981 Tectonics $14,19-38$.

982 Huang, C.-Y., Wu, W.Y., Chang, C.-P., Tsao, S., Yuan, P.B., Lin, C.W., Xia, K.Y., 1997. Tectonic evolution of 983 accretionary prism in the arc-continent collision terrane of Taiwan. Tectonophysics 281, 31-51.

984 Huang, C.-Y., Yuan, P.B., Lin, C.-W., Wang, T.K., Chang, C.-P., 2000. Geodynamic processes of Taiwan arc985 continent collision and comparison with analogs in Timor, Papua New Guinea, Urals and Corsica. 986 Tectonophysics 325, 1-21.

987 Huang, C.-Y., Yuan, P.B., Tsao, S.-J., 2006. Temporal and spatial records of active arc-continent collision in 988 Taiwan: A synthesis. Geological Society of America Bulletin 118, 274-288.

989 Huang, C.-Y., Chien, C.-W., Yao, B., Chang, C.-P., 2008. The Lichi Mélange: A collision mélange formation along 990 early arcward backthrusts during forearc basin closure, Taiwan arc-continent collision. In: Draut, A.E., Clift, 
This is a postprint submitted to the EarthArXiv by Larry Syu-Heng Lai

991 P.D., Scholl, D.W. (Eds.), Formation and Applications of the Sedimentary Record in Arc Collision Zones. 992 Geological Society of America Special Paper 436, pp. 127-154.

993 Huang, C.-Y., Chen, W.-H., Wang, M.-H., Lin, C.-T., Yang, S., Li, X., Yu, M., Zhao, X., Yang, K.-M., Liu, C.-S., 994 Hsieh, Y.-H., Harris, R., 2018. Juxtaposed sequence stratigraphy, temporal-spatial variations of sedimentation 995 and development of modern-forming forearc Lichi Mélange in North Luzon Trough forearc basin onshore and 996 offshore eastern Taiwan: An overview. Earth-Science Reviews 182, 102-140.

997 Huang, W.-J., Johnson, K.M., Fukuda, J.i., Yu, S.-B., 2010. Insights into active tectonics of eastern Taiwan from 998 analyses of geodetic and geologic data. Journal of Geophysical Research: Solid Earth 115, B03413. 999 https://doi.org/10.1029/2008JB006208.

1000 Jahn, B.M., Liou, J.G., 1977. Age and geochemical constraints of glaucophane schists of taiwan. Memoir of the 1001 Geological Society of China 2, 129-140.

1002 Keyser, W., Tsai, C.-H., Iizuka, Y., Oberhänsli, R., Ernst, W.G., 2016. High-pressure metamorphism in the 1003 Chinshuichi area, Yuli belt, eastern Taiwan. Tectonophysics 692, Part B, 191-202.

1004 Kirstein, L.A., Fellin, M.G., Willett, S.D., Carter, A., Chen, Y.-G., Graver, J.I., Lee, D.C., 2009. Pliocene onset of 1005 rapid exhumation in Taiwan during arc-continent collision: new insights from detrital thermochronometry. 1006 Basin Research 22, 270-285.

1007 Kirstein, L.A., Carter, A., Chen, Y.-G., 2014. Impacts of arc collision on small orogens: new insights from the 1008 Coastal Range detrital record, Taiwan. Journal of the Geological Society, London 171, 5-8.

1009 Kusky, T., Wang, J., Wang, L., Huang, B., Ning, W., Fu, D., Peng, H., Deng, H., Polat, A., Zhong, Y., Shi, G., 1010 2020. Mélanges through time: Life cycle of the world's largest Archean mélange compared with Mesozoic and 1011 Paleozoic subduction-accretion-collision mélanges. Earth-Science Reviews 209, 103303. 1012 https://doi.org/10.1016/j.earscirev.2020.103303.

1013 Lai, L.S.-H., Teng, L.S.-Y., 2016. Stratigraphy and structure of the Tai-Yuan basin, southern Coastal Range, eastern 1014 Taiwan. Bulletin of the Central Geological Survey, MOEA 29, 45-76. (in Chinese with English abstract). 
This is a postprint submitted to the EarthArXiv by Larry Syu-Heng Lai

1015 Lai, L.S.-H., Ng, T.-W., Teng, L.S.-Y., 2018. Stratigraphic correlation of tuffaceous and psephitic strata in the 1016 Paliwan formation, southern Coastal Range of eastern Taiwan. Bulletin of the Central Geological Survey, 1017 MOEA 31, 1-32. (in Chinese with English abstract).

1018 Lai, Y.-M., Song, S.-R., 2013. The volcanoes of an oceanic arc from origin to destruction: A case from the northern 1019 Luzon Arc. Journal of Asian Earth Sciences 74, 97-112.

1020 Lai, Y.-M., Song, S.-R., Lo, C.-H., Lin, T.-H., Chu, M.-F., Chung, S.-L., 2017. Age, geochemical and isotopic 1021 variations in volcanic rocks from the Coastal Range of Taiwan: Implications for magma generation in the $1022 \quad$ Northern Luzon Arc. Lithos 272-273, 92-115.

1023 Lai, Y.-M., Chu, M.-F., Chen, W.-S., Shao, W.-Y., Lee, H.-Y., Chung, S.-L., 2018. Zircon U-Pb and Hf isotopic 1024 constraints on the magmatic evolution of the Northern Luzon Arc. Terrestrial Atmospheric and Oceanic 1025 Sciences 29, 149-186.

1026 Lee, J.-C., Chu, H.-T., Angelier, J., Hu, J.-C., Chen, H.-Y., Yu, S.-B., 2006. Quantitative analysis of surface 1027 coseismic faulting and postseismic creep accompanying the 2003, Mw $=6.5$, Chengkung earthquake in eastern 1028 Taiwan. Journal of Geophysical Research: Solid Earth 111, B02405. https://doi.org/10.1029/2005JB003612. 1029 Lee, T.-Q., 1992. Study of the polarity transition record of the upper Olduvai event from Wulochi sedimentary 1030 sequence of the Coastal Range, eastern Taiwan. Terrestrial Atmospheric and Oceanic Sciences 3, 503-518.

1031 Lee, T.-Q., Chi, W.-R., 1990. Paleomagnetic dating of the sedimentary formations in the Coastal Range. Special 1032 Publication of the Central Geological Survey, MOEA 4, 271-294. (in Chinese with English abstract).

1033 Lee, T.-Q., Kissel, C., Laj, C., Horng, C.-S., Lue, Y.-T., 1990. Magnetic fabric analysis of the Plio-Pleistocene 1034 sedimentary formations of the Coastal Range of Taiwan. Earth and Planetary Science Letters 98, 23-32.

1035 Lee, Y.-H., Byrne, T., Wang, W.-H., Lo, W., Rau, R.-J., Lu, H.-Y., 2015. Simultaneous mountain building in the 1036 Taiwan orogenic belt. Geology 43, 451-454. https://doi.org/10.1016/0012-821X(90)90085-C.

1037 Li, M., 1984. Geology of Ruiyuan Area, Southern Coastal Range, Eastern Taiwan (M.Sc. thesis). National Taiwan 1038 University, Taipei, Taiwan, 74 pp. (in Chinese).

1039 Lin, A.T., Watts, A.B., Hesselbo, S.P., 2003. Cenozoic stratigraphy and subsidence history of the South China Sea 1040 margin in the Taiwan region. Basin Research 15, 453-478. 
This is a postprint submitted to the EarthArXiv by Larry Syu-Heng Lai

1041 Lin, C.W., Liu, Y.C., Lai, W.C., Cheng, W.H., 1999. Fault tectonics of the Coastal Range, eastern Taiwan. Journal 1042 of the Geological Society of China 42, 429-446.

1043 Lin, S.B., Chen, G.T., 1986. Clay minerals from the Lichi Melange and its adjacent formations in the Coastal Range, 1044 eastern Taiwan. Acta Geologica Taiwanica: Science Reports of the National Taiwan University 24, 319-356.

1045 Lin, W.-H., Lin, C.-W., Liu, Y.C., Chen, P.-T., 2008. Geological Map of Taiwan Scale 1:50,000 - Taitung and 1046 Jhihben Sheet. Central Geological Survey, MOEA, Taiwan, 58 pp. (in Chinese with English abstract).

1047 Liou, J.G., Suppe, J., Ernst, W.G., 1977. Conglomerates and pebbly mudstones in the Lichi Melange, eastern 1048 Taiwan. Memoir of the Geological Society of China 2, 115-128.

1049 Lo, H.-J., Chen, W.-S., Song, S.-R., 1993. Geological Map of Taiwan Scale 1:50,000 - Chengkung and Tungho 1050 Sheet. Central Geological Survey, MOEA, Taiwan, 63 pp. (in Chinese with English abstract) 1051 Lundberg, N., Dorsey, R.J., 1988. Synorogenic sedimentation and subsidence in a Plio-Pleistocene collisional basin, 1052 eastern Taiwan. In: Kleinspehn, K., Paola, C. (Eds.), New Perspectives in Basin Analysis. Frontiers in 1053 Sedimentary Geology. Springer, New York, pp. 265-280.

1054 Lundberg, N., Dorsey, R.J., 1990. Rapid Quaternary emergence, uplift, and denudation of the Coastal Range, 1055 eastern Taiwan. Geology 18, 638-641.

1056 Lundberg, N., Reed, D.L., Liu, C.S., Lieske, J., 1997. Forearc-basin closure and arc accretion in the submarine 1057 suture zone south of Taiwan. Tectonophysics 274, 5-23.

1058 Malavieille, J., Molli, G., Genti, M., Dominguez, S., Beyssac, O., Taboada, A., Vitale-Brovarone, A., Lu, C.-Y., 1059 Chen, C.-T., 2016. Formation of ophiolite-bearing tectono-sedimentary mélanges in accretionary wedges by 1060 gravity driven submarine erosion: Insights from analogue models and case studies. Journal of Geodynamics $1061 \quad 100,87-103$.

1062 Malavieille, J., Dominguez, S., Lu, C.-Y., Chen, C.-T., Konstantinovskaya, E., 2021. Deformation partitioning in 1063 mountain belts: insights from analogue modelling experiments and the Taiwan collisional orogen. Geological 1064 Magazine 158, 84-103. 
This is a postprint submitted to the EarthArXiv by Larry Syu-Heng Lai

1065 Mesalles, L., 2014. Mountain Building at a Subduction-Collision Transition Zone, Taiwan - Insights from 1066 Morphostructural Analysis and Thermochronological Dating (Ph.D. thesis). Université Pierre et Marie Curie, 1067 Paris, France, 336 pp.

1068 Mesalles, L., Lee, Y.-H., Ma, T.-C., Tsai, W.-L., Tan, X.-B., Lee, H.-Y., 2020. A Late-Miocene Yuli belt? New 1069 constraints on the eastern Central Range depositional ages. Terrestrial Atmospheric and Oceanic Sciences 31, $1070 \quad 403-414$.

1071 Michiguchi, Y., Ogawa, Y., Wakabayashi, J., Dilek, Y., 2011. Implication of dark bands in Miocene-Pliocene 1072 accretionary prism, Boso Peninsula, central Japan. In: Wakabayashi, J., Dilek, Y. (Eds.), Mélanges: Processes 1073 of Formation and Societal Significance. The Geological Society of America Special Paper 480, pp. 247-260. 1074 Moore, G.F., Aung, L.T., Fukuchi, R., Sample, J.C., Hellebrand, E., Kopf, A., Naing, W., Than, W.M., Tun, T.N., 1075 2019. Tectonic, diapiric and sedimentary chaotic rocks of the Rakhine coast, western Myanmar. Gondwana $1076 \quad$ Research 74, 126-143.

1077 Nagel, S., Castelltort, S., Garzanti, E., Lin, A.T., Willett, S.D., Mouthereau, F., Limonta, M., Adatte, T., 2014. 1078 Provenance evolution during arc-continent collision: sedimentary petrography of Miocene to Pleistocene 1079 sediments in the western foreland basin of Taiwan. Journal of Sedimentary Research 84, 513-528.

1080 Nemec, W., 1990. Aspects of sediment movement on steep delta slopes. In: Colella, A., Prior, D.B. (Eds.), Coarse1081 Grained Deltas. Special Publication of the International Association of Sedimentologists 10, pp. 29-73.

1082 Noda, A., 2016. Forearc basins: Types, geometries, and relationships to subduction zone dynamics. Geological $1083 \quad$ Society of America Bulletin 128, 879-875.

1084 Noda, A., 2018. Forearc basin stratigraphy and interactions with accretionary wedge growth according to the critical 1085 taper concept. Tectonics 37, 965-988.

1086 Ogata, K., Mutti, E., Pini, G.A., Tinterri, R., 2012. Mass transport-related stratal disruption within sedimentary 1087 mélanges: Examples from the northern Apennines (Italy) and south-central Pyrenees (Spain). Tectonophysics $1088 \quad 568-569,185-199$. 
This is a postprint submitted to the EarthArXiv by Larry Syu-Heng Lai

1089 Ogata, K., Mountjoy, J.J., Pini, G.A., Festa, A., Tinterri, R., 2014. Shear zone liquefaction in mass transport deposit 1090 emplacement: A multi-scale integration of seismic reflection and outcrop data. Marine Geology 356, 50-64.

1091 Ogata, K., Festa, A., Pini, G.A., Alonso, J.L., 2019a. Submarine landslide deposits in orogenic belts. In: Ogata, K., 1092 Festa, A., Pini, G.A. (Eds.), Submarine Landslides: Subaqueous Mass Transport Deposits from Outcrops to 1093 Seismic Profiles. John Wiley \& Sons, Inc., Hoboken, NJ, USA and American Geophysical Union, Washington, 1094 D.C., USA, pp. 1-26.

1095 Ogata, K., Festa, A., Pini, G.A., Pogačnik, Ž., Lucente, C.C., 2019b. Substrate deformation and incorporation in 1096 sedimentary mélanges (olistostromes): Examples from the northern Apennines (Italy) and northwestern 1097 Dinarides (Slovenia). Gondwana Research 74, 101-125.

1098 Ogg, J.G., 2012. Geomagnetic polarity time scale. In: Gradstein, F.M., Ogg, J.G., Schmitz, M.D., Ogg, G.M. (Eds.), 1099 The Geologic Time Scale 2012. Elsevier, Boston, USA, pp. 85-113.

1100 Ooe, G., 1939. Geologic Map of Taiwan, Taito Sheet. Goverment General of Taiwan, 1-26.

1101 Page, B.M., Suppe, J., 1981. The Pliocene Lichi Mélange of Taiwan: its plate-tectonic and olistostromal origin. 1102 American Journal of Science 281, 193-227.

1103 Ragan, D.M., 2009. Structural Geology: An Introduction to Geometrical Techniques. Cambridge University Press, 1104 Cambridge, UK, 602 pp.

1105 Ramsay, J.G., 1961. The effects of folding upon the orientation of sedimentation structures. The Journal of Geology $1106 \quad 69,84-100$.

1107 Raymond, L.A., 1984. Classification of melanges. In: Raymond, L.A. (Ed.), Melanges: Their Nature, Origin, and 1108 Significance. The Geological Society of America Special Paper 198, pp. 7-20.

1109 Raymond, L.A., 2019. Perspectives on the roles of melanges in subduction accretionary complexes: A review. 1110 Gondwana Research 74, 68-89.

1111 Reed, D.L., Lundberg, N., Liu, C.-S., Kuo, B.Y., 1992. Structural relations along the margins of the offshore Taiwan 1112 accretionary wedge: implications for accretion and crustal kinematics. Acta Geologica Taiwanica: Science 1113 Reports of the National Taiwan University 30, 105-122. 
This is a postprint submitted to the EarthArXiv by Larry Syu-Heng Lai

1114 Sandmann, S., Nagel, T.J., Froitzheim, N., Ustaszewski, K., Münker, C., 2015. Late Miocene to Early Pliocene 1115 blueschist from Taiwan and its exhumation via forearc extraction. Terra Nova 27, 285-291.

1116 Shyu, C.-T., Chih, M.-C., Hsu, S.-K., Wang, C., Karp, B., 1996. Northern Luzon Arc: Location and tectonic features 1117 from magnetic data off eastern Taiwan. Terrestrial Atmospheric and Oceanic Sciences 7, 535-548.

1118 Silver, E.A., Beutner, E.C., 1980. Melanges. Geology 8, 32-34.

1119 Sinclair, H.D., 2012. Thrust wedge/foreland basin systems. In: Busby, C., Azor, A. (Eds.), Tectonics of Sedimentary 1120 Basins: Recent Advances. John Wiley \& Sons, Ltd, Chichester, UK, pp. 522-537.

1121 Sinclair, H.D., Naylor, M., 2012. Foreland basin subsidence driven by topographic growth versus plate subduction. 1122 Geological Society of America Bulletin 124, 368-379.

1123 Song, S.-R., Lo, H.-J., 2002. Lithofacies of volcanic rocks in the central Coastal Range, eastern Taiwan: 1124 implications for island arc evolution. Journal of Asian Earth Sciences 21, 23-38.

1125 Song, S.-R., Tang, H.-Y., 2019. Tuff layers in the fore-arc basin of south Coastal Range, eastern Taiwan: 1126 Implications for volcanic activity and evolution after the arc-continent collision. American Geophysical Union, 1127 Fall Meeting, 9-13 December, 2019, San Francisco, California, USA. Abstract \#V31D-0159.

1128 Song, S.-R., Lo, H.-J., Chen, W.-S., 1994. Origin of clastic dikes In the Coastal Range, eastern Taiwan with 1129 implications for sedimentary processes during the arc-continent collision. Journal of the Geological Society of $1130 \quad$ China $37,407-424$.

1131 Stanley, R.S., Hill, L.B., Chang, H.C., Hu, H.-N., 1981. A transect through the metamorphic core of the central 1132 mountains, southern Taiwan. Memoir of the Geological Society of China 4, 443-473.

1133 Stow, D.A.V., Mayall, M., 2000. Deep-water sedimentary systems: New models for the 21st century. Marine and 1134 Petroleum Geology 17, 125-135.

1135 Sun, C.-H., Smith, A.D., Chen, C.-H., 1998. Nd-Sr isotopic and geochemical evidence on the protoliths of exotic 1136 blocks in the Juisui Area, Yuli Belt, Taiwan. International Geology Review 40, 1076-1087.

1137 Sung, Q., 1991. Some characteristics of sedimentary blocks in the Lichi Mélange, Coastal Range, Taiwan. Special 1138 Publication of the Central Geological Survey, MOEA 5, 231-256. (in Chinese with English abstract). 
This is a postprint submitted to the EarthArXiv by Larry Syu-Heng Lai

1139 Suppe, J., 1984. Kinematics of Arc-Continent Collision, Flipping of Subduction, and Back-Arc Spreading Near 1140 Taiwan. Memoir of the Geological Society of China 3, 21-33.

1141 Suppe, J., Liou, J.G., 1979. Tectonics of the Lichi Mélange and East Taiwan Ophiolite. Memoir of the Geological 1142 Society of China 6, 147-153.

1143 Tate, G.W., McQuarrie, N., van Hinsbergen, D.J.J., Bakker, R.R., Harris, R., Jiang, H., 2015. Australia going down 1144 under: Quantifying continental subduction during arc-continent accretion in Timor-Leste. Geosphere 11, 1860$1145 \quad 1883$.

1146 Teng, L.S., 1979. Petrographical study of the Neogene sandstones of the Coastal Range, eastern Taiwan (I. northern 1147 part). Acta Geologica Taiwanica: Science Reports of the National Taiwan University 20, 129-156.

1148 Teng, L.S., 1980. Lithology and provenance of the Fanshuliao formation, northern Coastal Range, eastern Taiwan. 1149 Proceedings of the Geological Society of China 23, 118-129.

1150 Teng, L.S., 1981. On the origin and tectonic significance of the Lichi Formation, Coastal Range, eastern Taiwan. 1151 Ti-Chih 3, 51-61. (in Chinese with English abstract).

1152 Teng, L.S., 1982. Stratigraphy and sedimentation of the Suilien conglomerate, northern Coastal Range, eastern 1153 Taiwan. Acta Geologica Taiwanica: Science Reports of the National Taiwan University 21, 201-220.

1154 Teng, L.S., 1987. Tectostratigraphic facies and geologic evolution of the Coastal Range, eastern Taiwan. Memoir 1155 of the Geological Society of China 8, 229-250.

1156 Teng, L.S., 1990. Geotectonic evolution of late Cenozoic arc-continent collision in Taiwan. Tectonophysics 183, $1157 \quad 57-76$.

1158 Teng, L.S., Chen, W.-S., Wang, Y., Song, S.-R., Lo, H.-J., 1988. Toward a comprehensive stratigraphic system of 1159 the Coastal Range, eastern Taiwan. Acta Geologica Taiwanica: Science Reports of the National Taiwan $1160 \quad$ University $26,19-35$.

1161 Teng, L.S., Lee, J.C., Hsu, C.B., 2002. Soft-sediment deformation in the Fanshuliao formation of the Coastal Range, 1162 eastern Taiwan. Bulletin of the Central Geological Survey, MOEA 15, 103-137. (in Chinese with English 1163 abstract). 
This is a postprint submitted to the EarthArXiv by Larry Syu-Heng Lai

1164 Tensi, J., Mouthereau, F., Lacombe, O., 2006. Lithospheric bulge in the West Taiwan Basin. Basin Research 18, $1165 \quad 277-299$.

1166 Thomas, M.Y., Avouac, J.-P., Gratier, J.-P., Lee, J.-C., 2014. Lithological control on the deformation mechanism 1167 and the mode of fault slip on the Longitudinal Valley Fault, Taiwan. Tectonophysics 632, 48-63.

1168 Tripsanas, E.K., Piper, D.J.W., Jenner, K.A., Bryant, W.R., 2008. Submarine mass-transport facies: new 1169 perspectives on flow processes from cores on the eastern North American margin. Sedimentology 55, 97-136.

1170 Tsai, M.-C., Yu, S.-B., Shin, T.-C., Kuo, K.-W., Leu, P.-L., Chang, C.-H., Ho, M.-Y., 2015. Velocity field derived 1171 from Taiwan continuous GPS array (2007 - 2013). Terrestrial Atmospheric and Oceanic Sciences 26, 527-556.

1172 Wakabayashi, J., 2019. Sedimentary compared to tectonically-deformed serpentinites and tectonic serpentinite 1173 mélanges at outcrop to petrographic scales: Unambiguous and disputed examples from California. Gondwana $1174 \quad$ Research 74, 51-67.

1175 Wang, C.S., 1976. The Lichi Formation of the Coastal Range and arc-continent collision In eastern Taiwan. Bulletin 1176 of the Geological Survey of Taiwan 25, 73-86.

1177 Wang, J., Li, X., Ning, W., Kusky, T., Wang, L., Polat, A., Deng, H., 2019. Geology of a Neoarchean suture: 1178 Evidence from the Zunhua ophiolitic mélange of the Eastern Hebei Province, North China Craton. Geological 1179 Society of America Bulletin 131, 1943-1964.

1180 Wang, Y., Chen, W.-S., 1993. Geological Map of Eastern Coastal Range. Central Geological Survey, MOEA, 1181 Taiwan. (in Chinese with English abstract).

1182 Yang, T.F., Tien, J.-1., Chen, C.-H., Lee, T., Punongbayan, R.S., 1995. Fission-track dating of volcanics in the 1183 northern part of the Taiwan-Luzon Arc: eruption ages and evidence for crustal contamination. Journal of 1184 Southeast Asian Earth Sciences 11, 81-93.

1185 Yang, T.F., Lee, T., Chen, C.-H., Cheng, S.-N., Knittel, U., Punongbayan, R.S., Rasdas, A.R., 1996. A double island 1186 arc between Taiwan and Luzon: consequence of ridge subduction. Tectonophysics 258, 85-101.

1187 Yao, T.M., Tien, P.L., Wang Lee, C.-M., 1988. Clay mineralogical studies on the Neogene formations, Taiyuan 1188 Basin, southern Coastal Range of Taiwan. Acta Geologica Taiwanica: Science Reports of the National Taiwan 1189 University 26, 263-277. 
This is a postprint submitted to the EarthArXiv by Larry Syu-Heng Lai

1190 Yen, J.Y., Lu, C.H., Dorsey, R.J., Kuo-Chen, H., Chang, C.P., Wang, C.C., Chuang, R.Y., Kuo, Y.T., Chiu, C.Y., 1191 Chang, Y.H., Bovenga, F., Chang, W.Y., 2018. Insights into seismogenic deformation during the 2018 Hualien, 1192 Taiwan, earthquake sequence from InSAR, GPS, and modeling. Seismological Research Letters 90, 78-87.

1193 Yu, S.-B., Chen, H.-Y., Kuo, L.-C., 1997. Velocity field of GPS stations in the Taiwan area. Tectonophysics 274, $1194 \quad 41-59$.

1195 


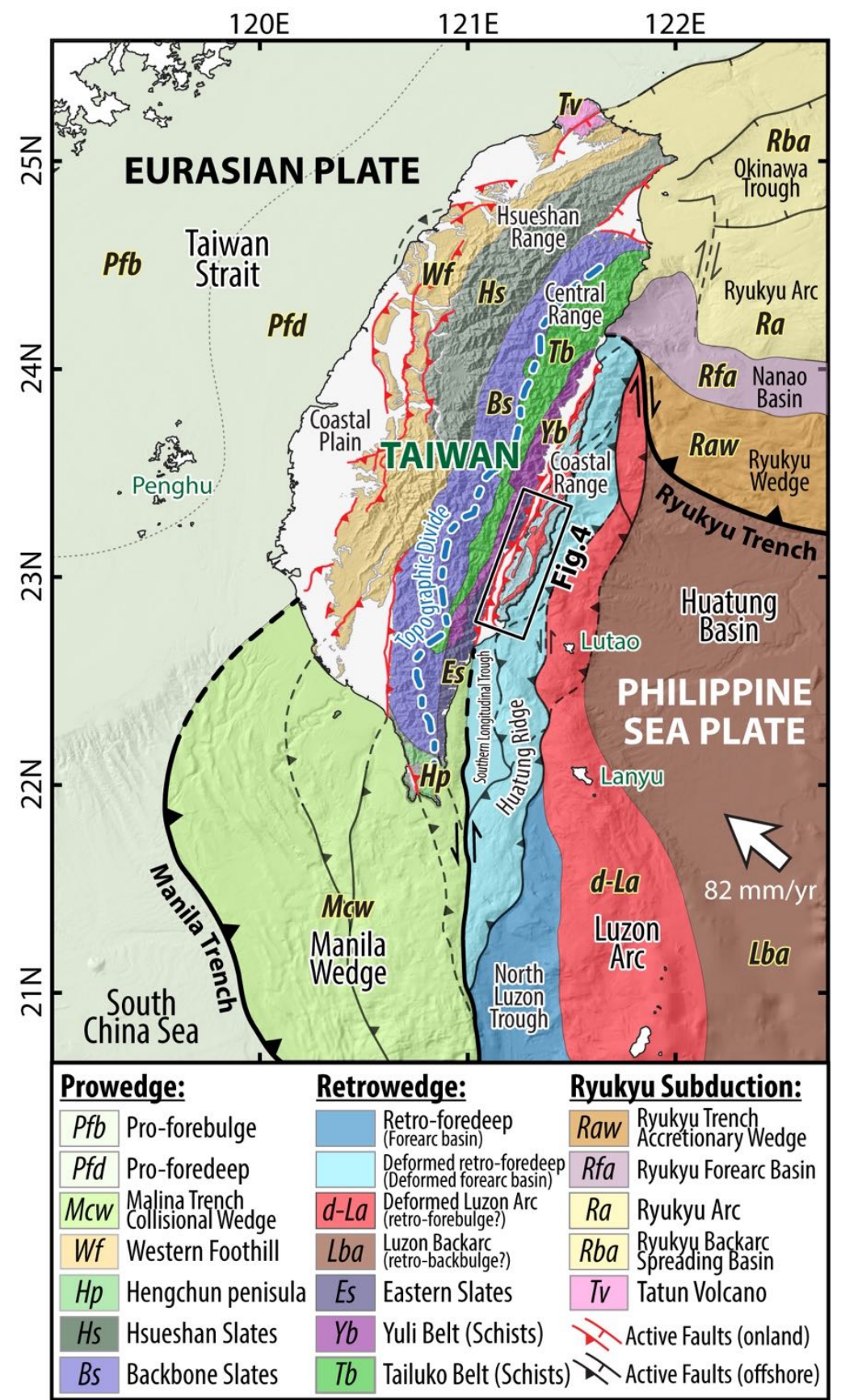

Figure 1. Geological setting. Plate configuration and tectonic domains at Taiwan arc-continent collision, synthesized and modified from previous studies (Lin et al., 2003; Huang et al., 2018; Chen et al., 2019; Malavieille et al., 2021). 


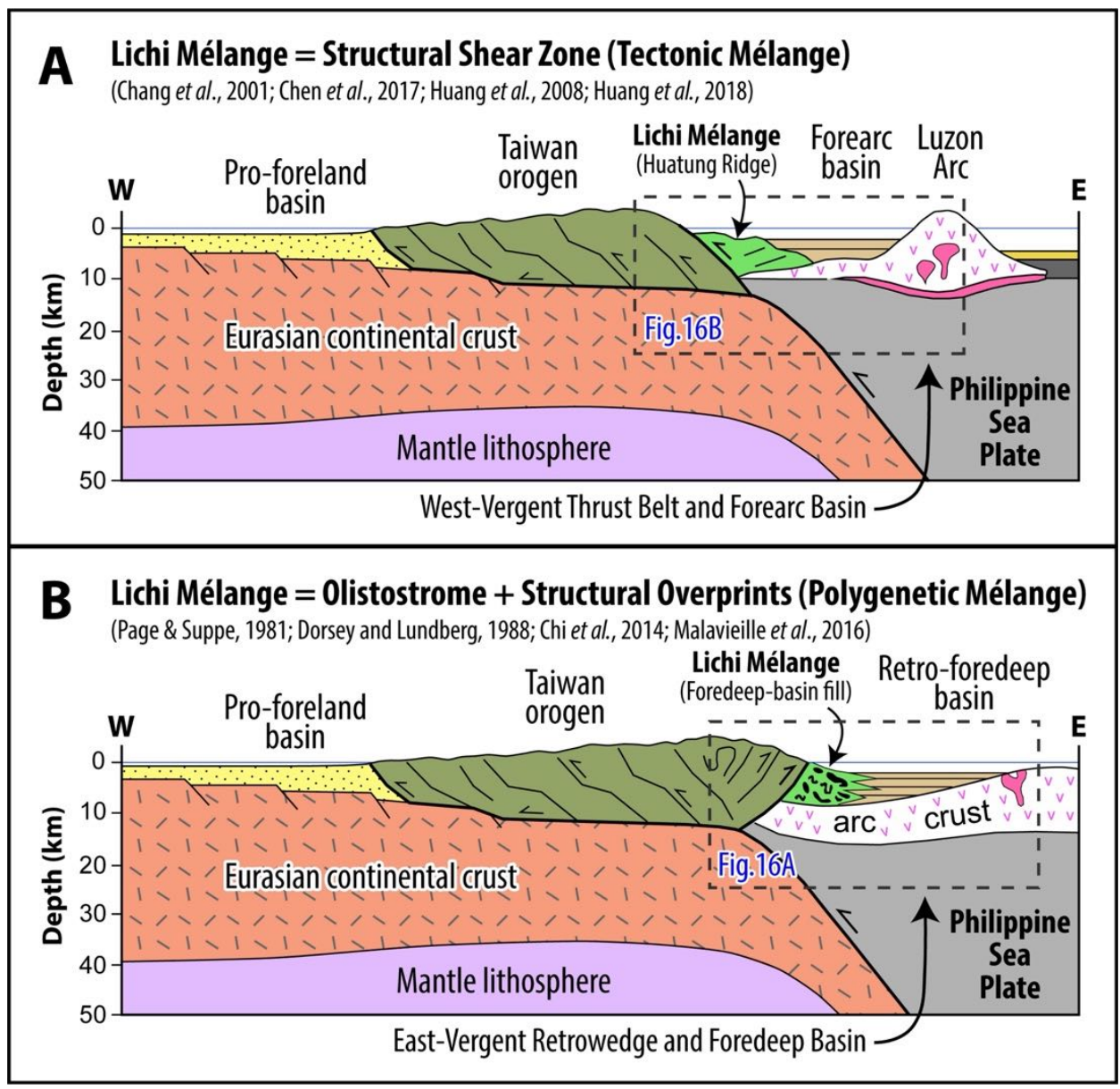

Figure 2. Comparison of published models for the origin and tectonic controls on formation of the Lichi Mélange. Figures are identical in the western half (central Taiwan orogen to pro-foreland basin); all differences are expressed in the eastern half, at the complex interface between Eurasian and Philippine Sea plates (dashed box). (A) Plate configuration and tectonic domains at Taiwan arc-continent collision, synthesized and modified from Huang et al. (2018). (B) Lichi Mélange originated as a sequence of marine mega-slumps (olistostromes) formed in a synorogenic foredeep basin at the east margin of the east-vergent retrowedge zone of the Taiwan orogen, modified from Malavieille et al. (2016). 
1213

1215

1216

1217

1218

1219

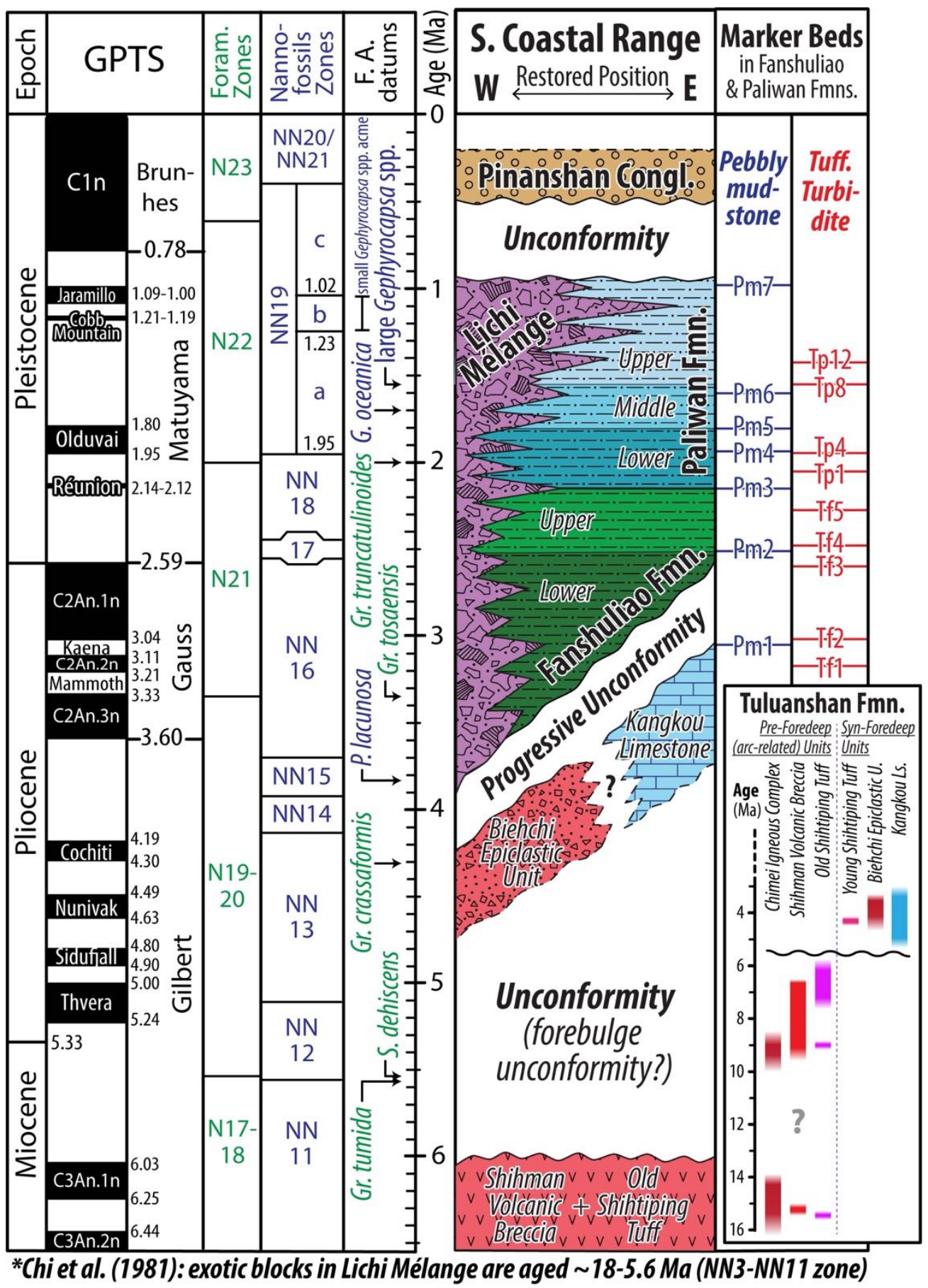

Figure 3. Stratigraphic framework of southern Coastal Range (modified from Dorsey, 1992; Lai and Teng, 2016; Lai, L.S.-H. et al., 2018). The geomagnetic polarity timescale (GPTS) and microfossils' first appearance (F.A.) datums of Indo-Pacific region are summarized (Anthonissen and Ogg, 2012; Backman et al., 2012; Ogg, 2012; Chuang et al., 2018). The lower right inset shows ages compiled for the entire Tuluanshan Formation (Huang et al., 1988; Dorsey, 1992; Huang and Yuan, 1994; Chen, 2009; Lai, Y.-M. et al., 2018). 


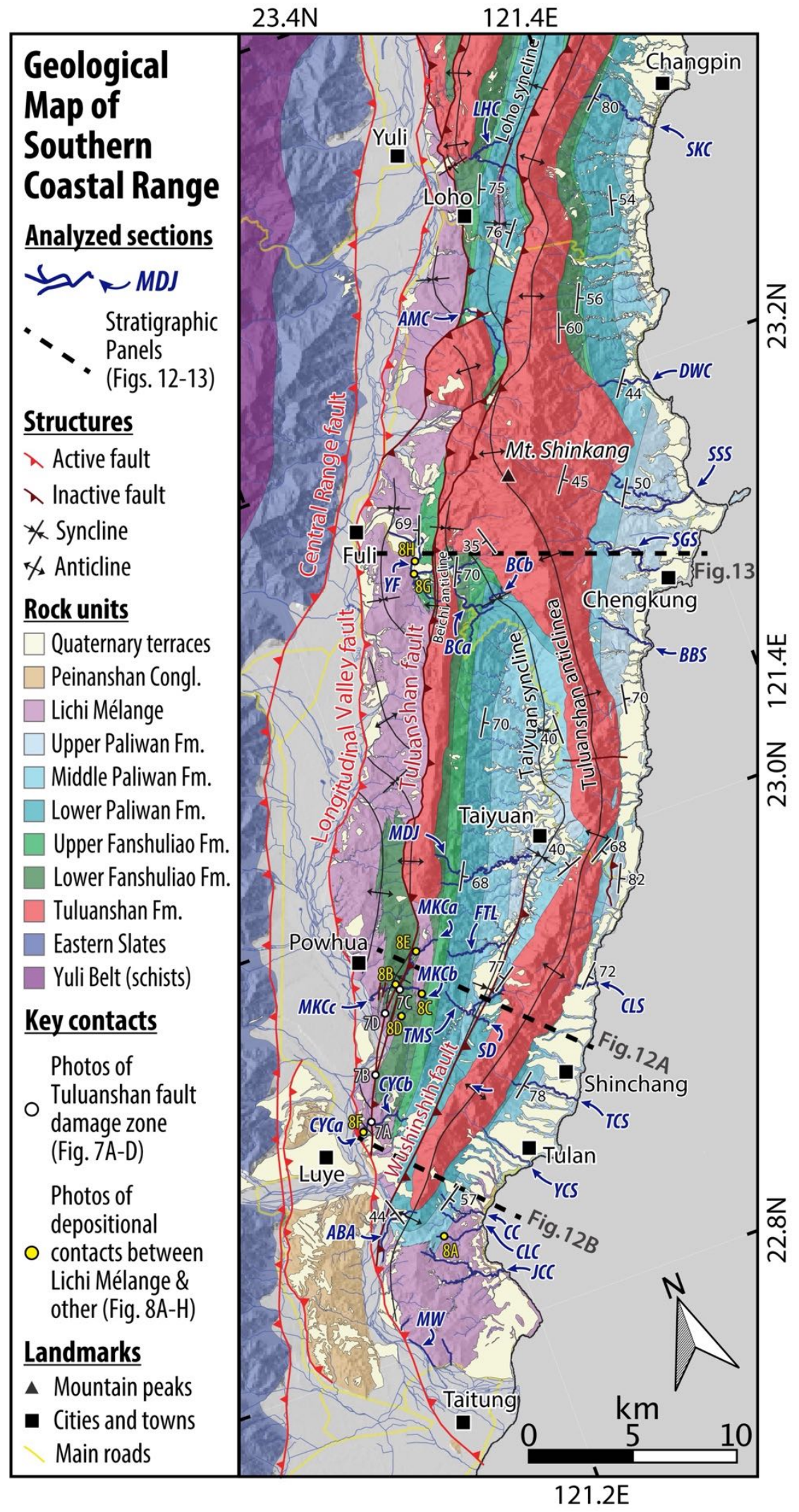

Figure 4. Geological map of southern Coastal Range (modified from Wang and Chen, 1993; Lai and Teng, 2016; Lai, L.S.-H. et al., 2018). See detail maps in Figs. S1-S9. 

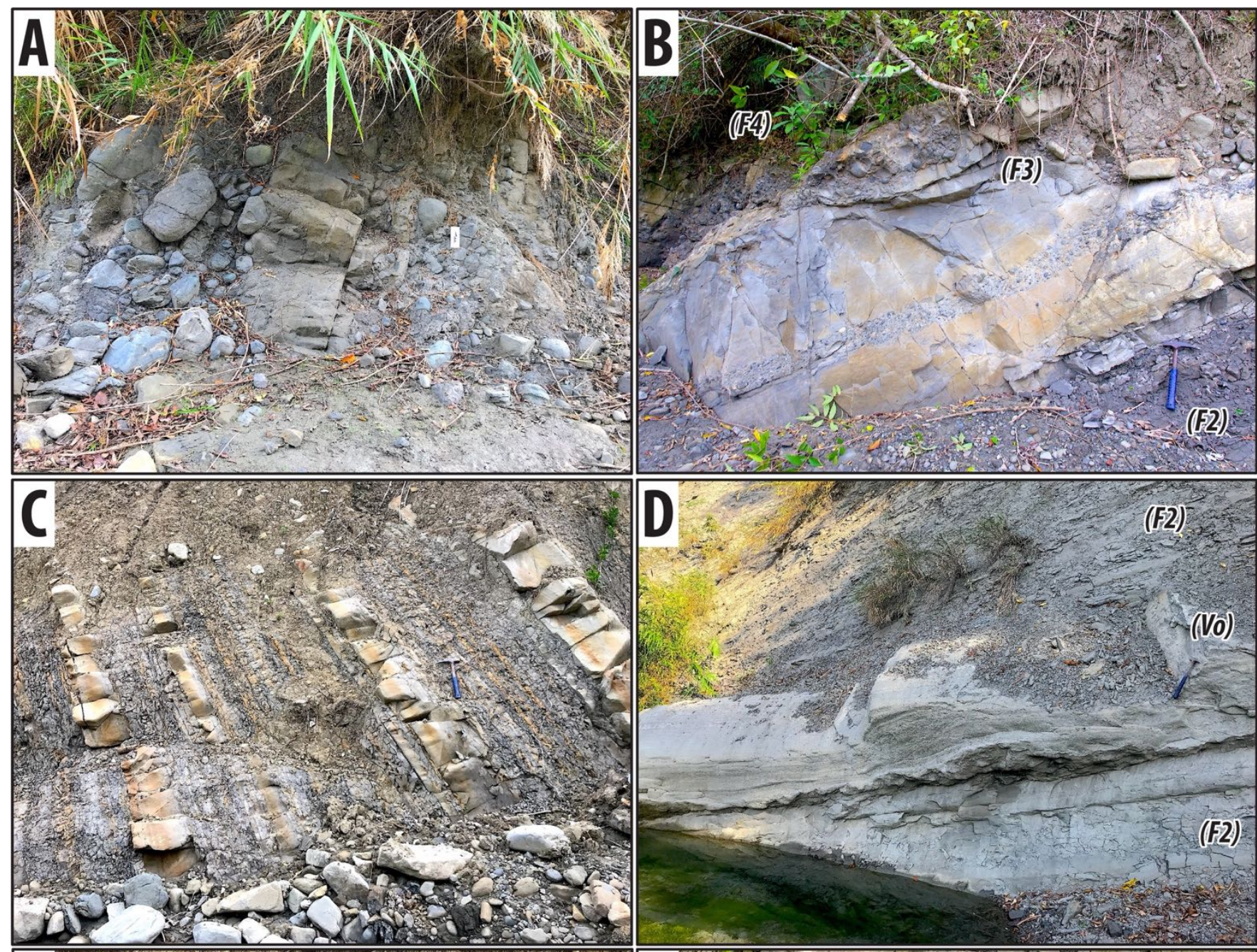

1224

1226

1227

1228

1229

1230
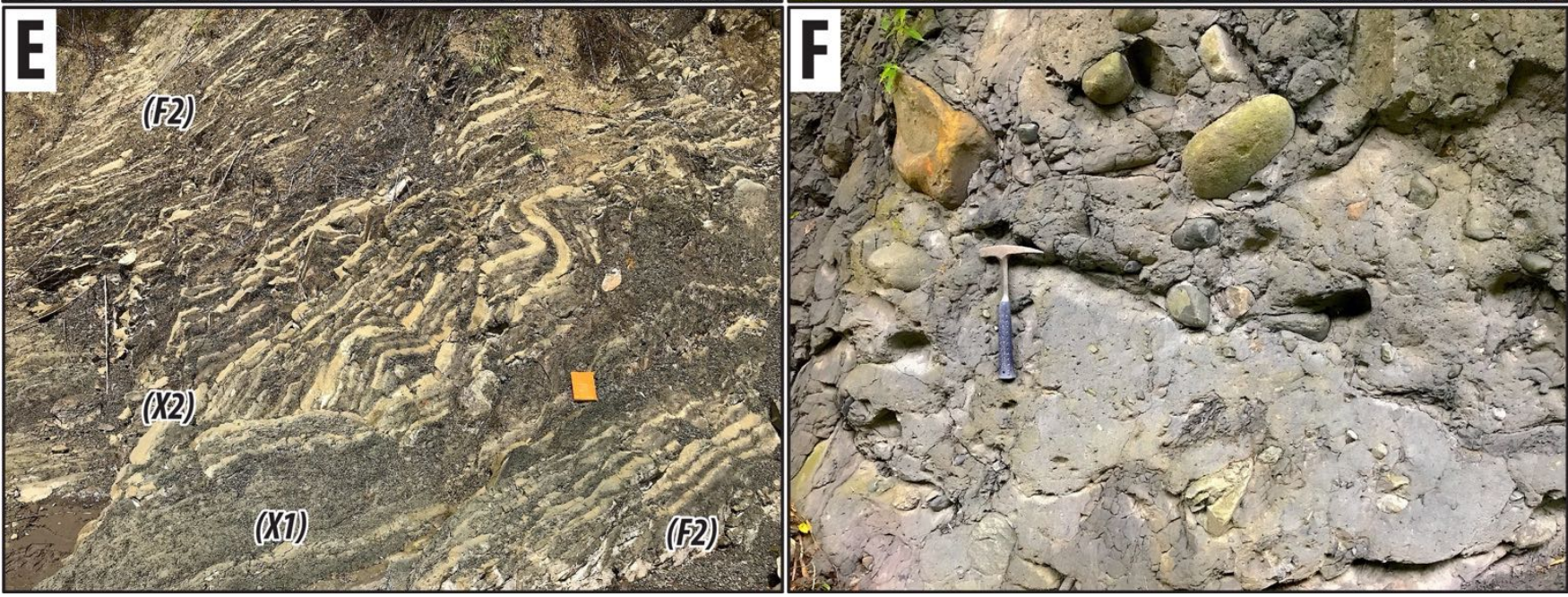

Figure 5. Lithofacies photos - I: products of sediment gravity flows. (A) Conglomerate (F4) in Mukeng river - C (MKCc) section. Notes the bedding is overturned; (B) Thick-bedded sandstone and gritstone (F3) in MKCc section, associated with conglomerate (F4) and turbidite (F2); (C) Turbidite (F2) and interbedded mudstone (F1) in Mukeng river - B (MKCb) section; (D) Tuffaceous turbidite (Vo of Tp12), interbeds with orogen-derived turbidites (F2) in Madagida river (MDJ) section; (E) Slump bed (X2) associated with pebbly mudstone Pm1 (X1) and turbidites (F2) in MKCc section; (F) Pebbly mudstone Pm3 (X1) in MDJ section. 

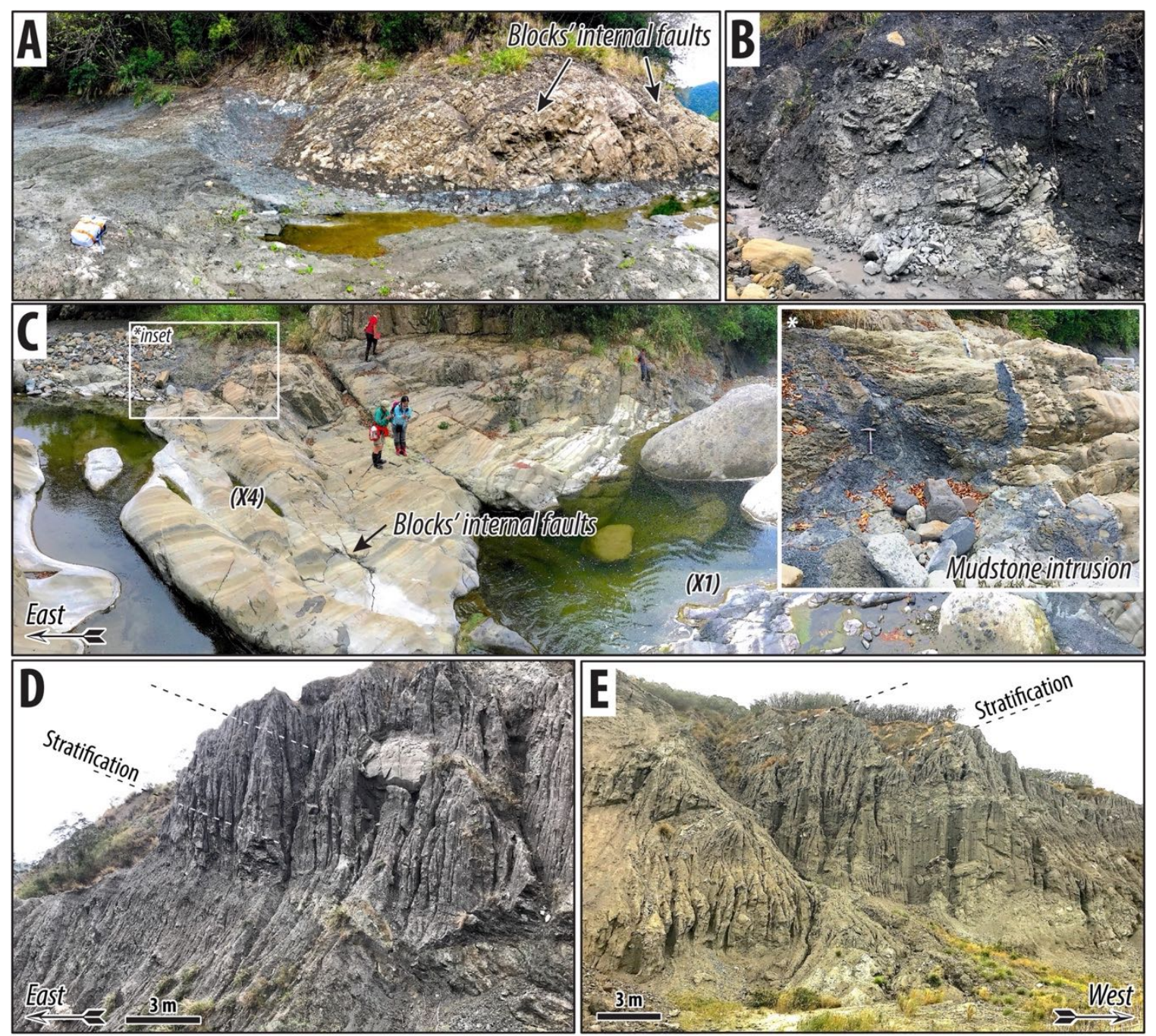

1231

1233

1234

1235

1236

1237

1238

1239

1240
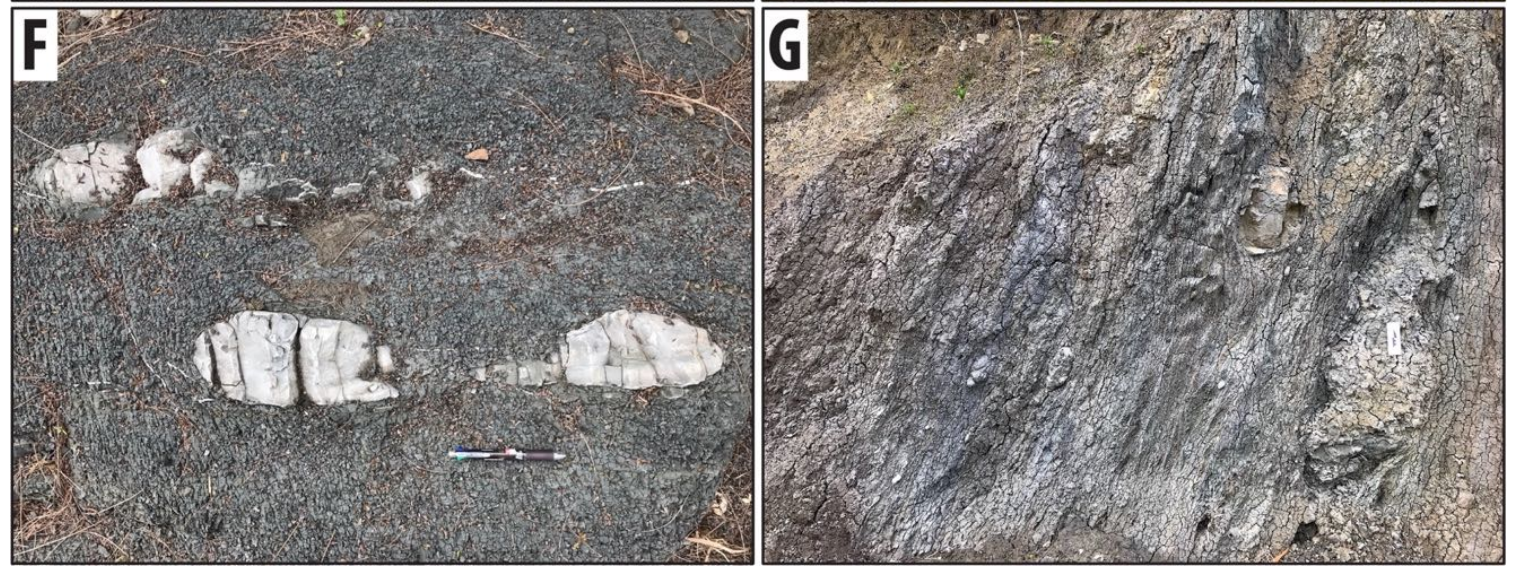

Figure 6. Lithofacies photos - II: products of mass wasting. (A) Volcaniclastic (andesitic) sandstone olistoliths (X4) embedded in slump bed (X2) with soft-sediment deformation at Yungfong (YF) section. Notes the internal faults in blocks truncated at blocks' margins; (B) Sandstone olistoliths (X4) with soft-sediment deformation in olistostrome (X3) at Mukeng river - A (MKCa) section; (C) Volcaniclastic (andesitic) sandstone olistoliths (X4) with muddy injectites (inset) in Bieh river - A (BCa) section, associated with pebbly mudstone Pm2 (X1) and slump bed (X2); (D) olistostrome (X3) in Juchiang river (JCC) section with south-dipping stratifications; (E) olistostrome (X3) in Moon World (MW) section with east-dipping stratifications; (F) Sedimentary boudinages in slump bed (X2) at Mukeng river - C (MKCc) section (i.e., broken formation); (G) Scaly foliation and sigmoidal-shaped blocks formed by non-coaxial shear and extensional fracturing (block-inmatrix fabrics) in a sheared horizon near a basal contact of olistostrome (X3) facies at MKCc section. 

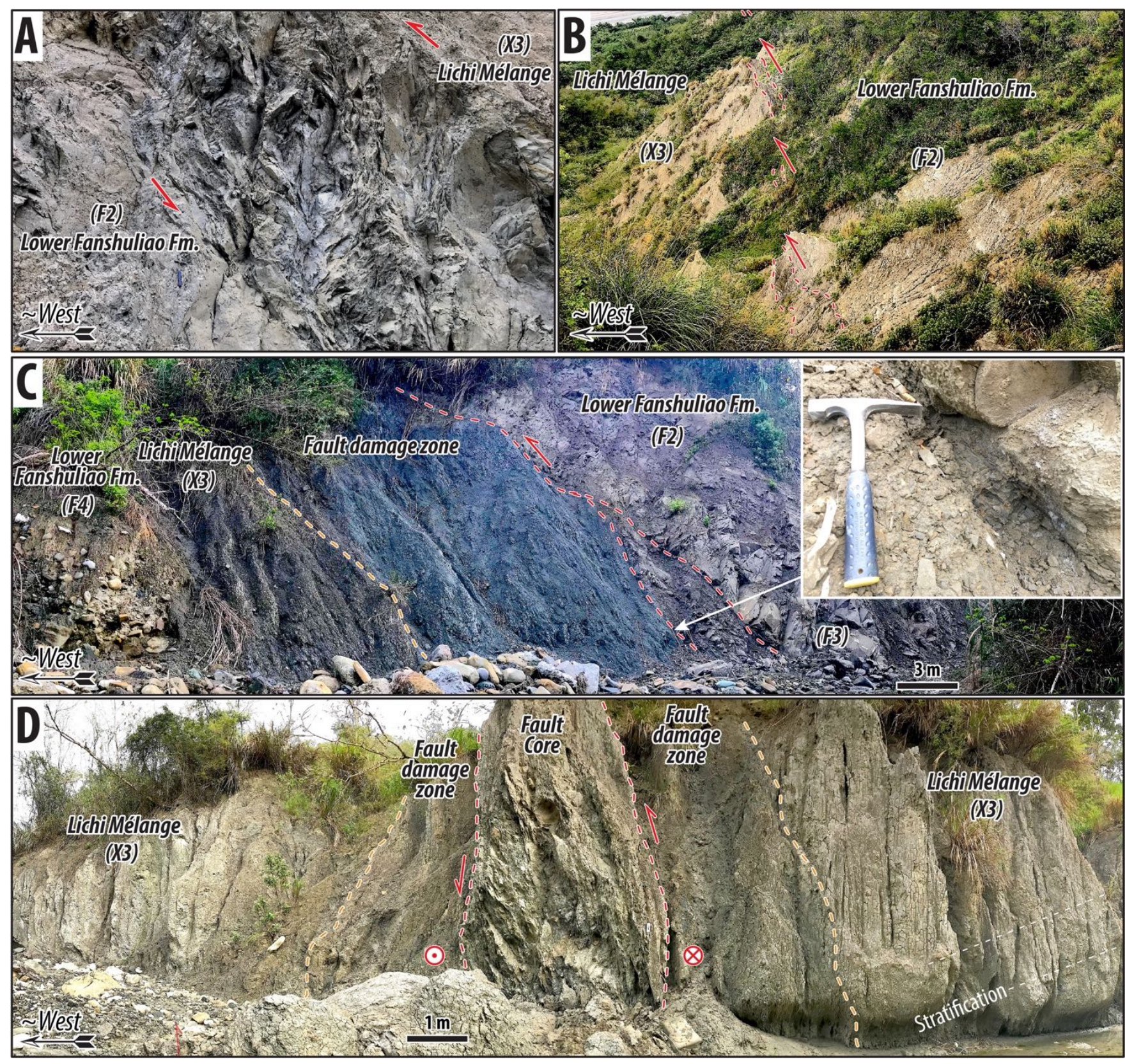

1241

1243

1244

1245

1246

1247
Figure 7. Field photos for Tulaunshan fault damage zone and core (uncompacted cataclasite and/or gouge zone). (A) Tuluanshan fault cataclasite in Chungye river (CYC) section; (B) Gouge zone (bounded by red dash lines) of the Tuluanshan fault along Road no.192; (C) Tuluanshan fault zone in at the base of Mukeng river - B (MKCb) section. The inset shows exposed fault gouge. Pencil cleavage exists in footwall broken formation (Br); (D) Tuluanshan fault zone along Mukengnan river, equivalent to site \#19 in Chang et al. (2000). See locations in Fig. 4. 


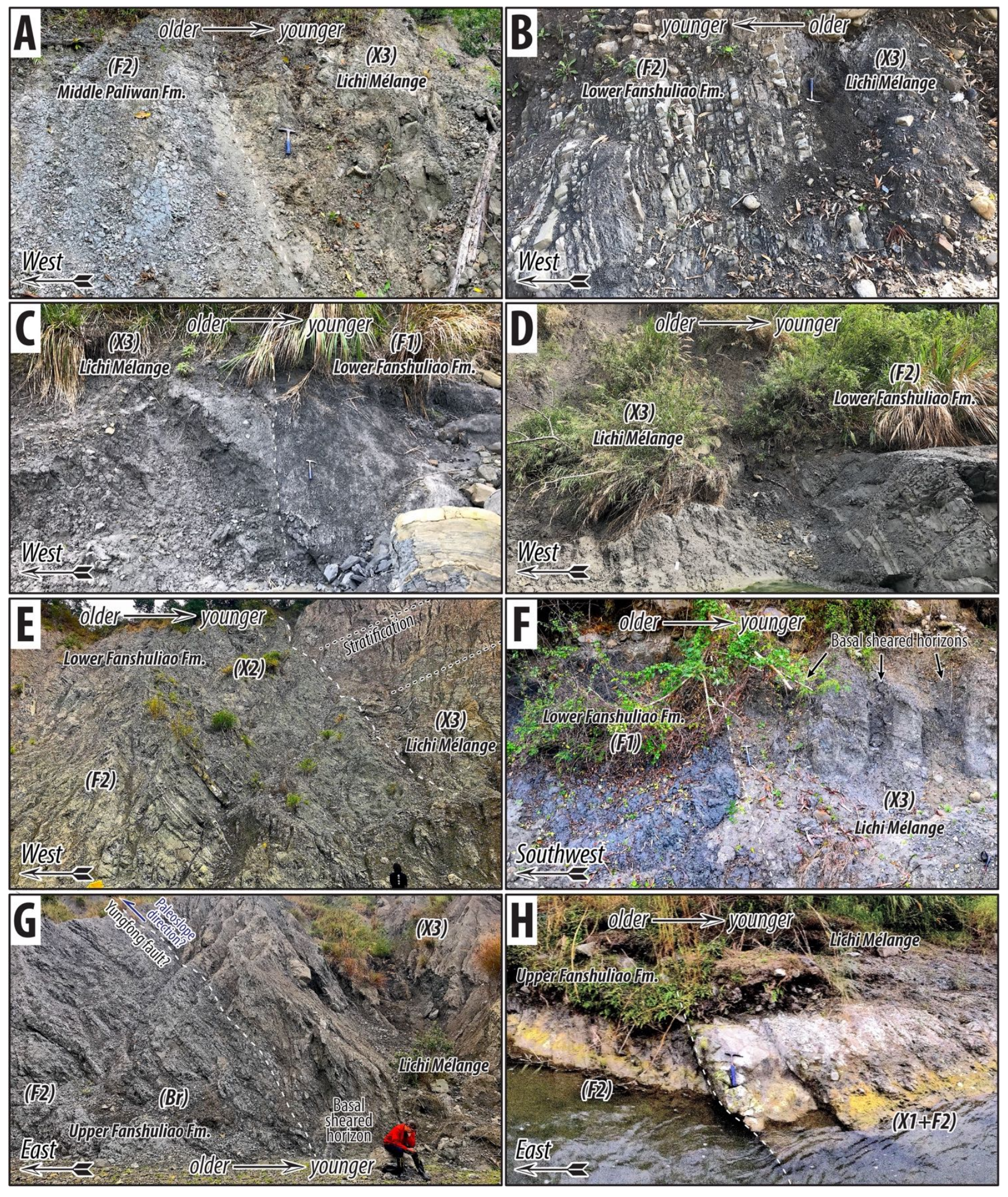

Figure 8. Field photos for depositional contacts (white dash lines) between Lichi Mélange \& other units. (A) Chiaolai river (CLC) section, same place as 'Locality J' in Page and Suppe (1981); (B) Mukeng river - C (MKCc) section. Notes the bedding is overturned; (C) Mukeng river - B (MKCb) section; (D) Mukengnan river section upstream; (E) MKCa section downstream. The stratifications (black dash lines) of olistostrome (X3) appears to onlap on an erosive contact (white dash lines) locally truncating on lower Fanshuliao formation; (F) Chungye river - A (CYCa) section; (G-H) southern and northern contacts of Yungfong (YF) section respectively, which was previously inferred to the "Yungfong fault" (Chen, 1997; Chang et al., 2000). See locations in Fig. 4. 


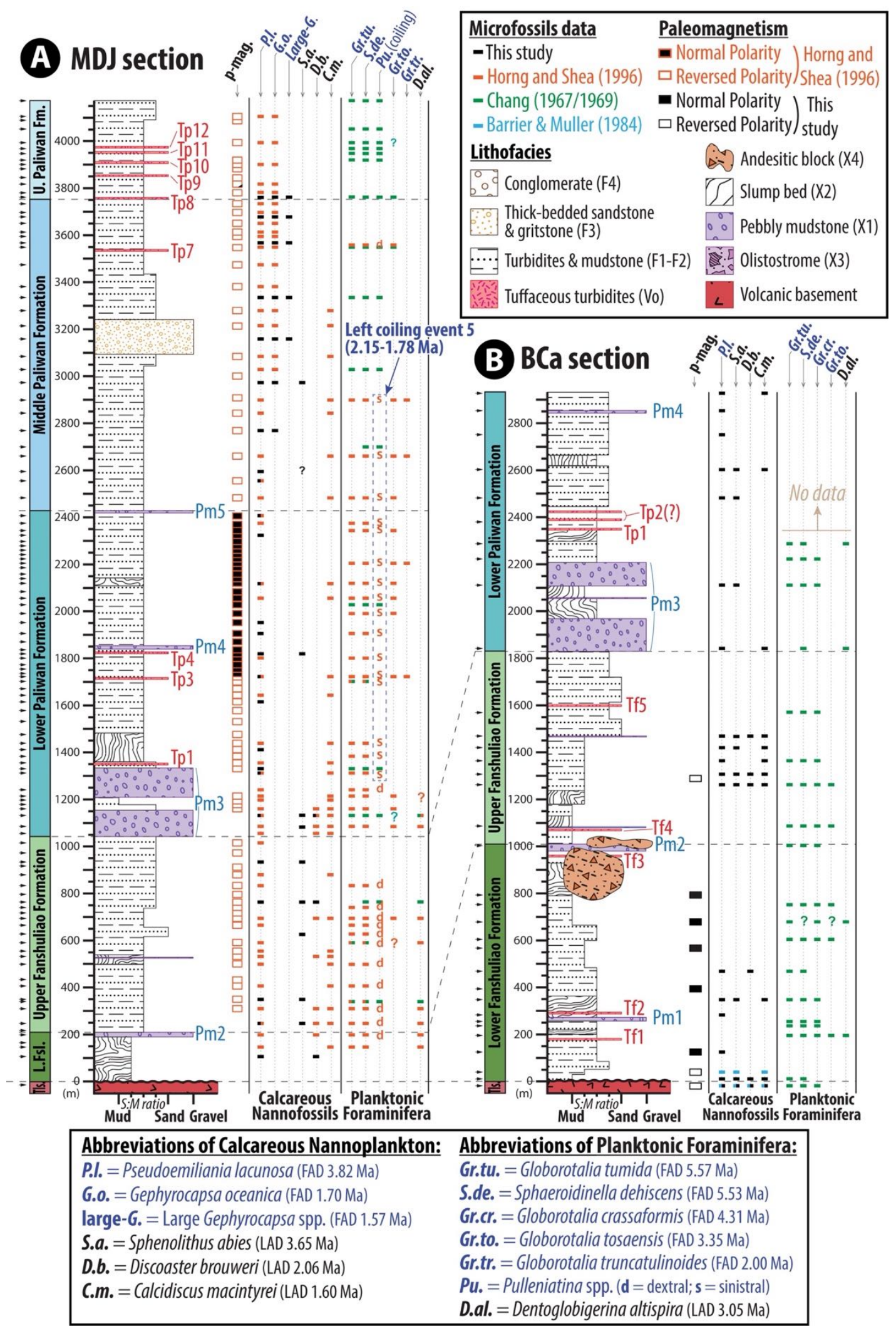

Figure 9. Type sections for Fanshuliao and Paliwan formations in the southern Coastal Range. (A) Madagida river (MDJ) section; (B) Bieh river - A (BCa) section. Black arrow heads on the left mark the stratigraphic heights of magneto-biostratigraphic constraints. See detail sample numbers in Figs. S1, S5, S8, S11 and data in Tables S3, S5. 


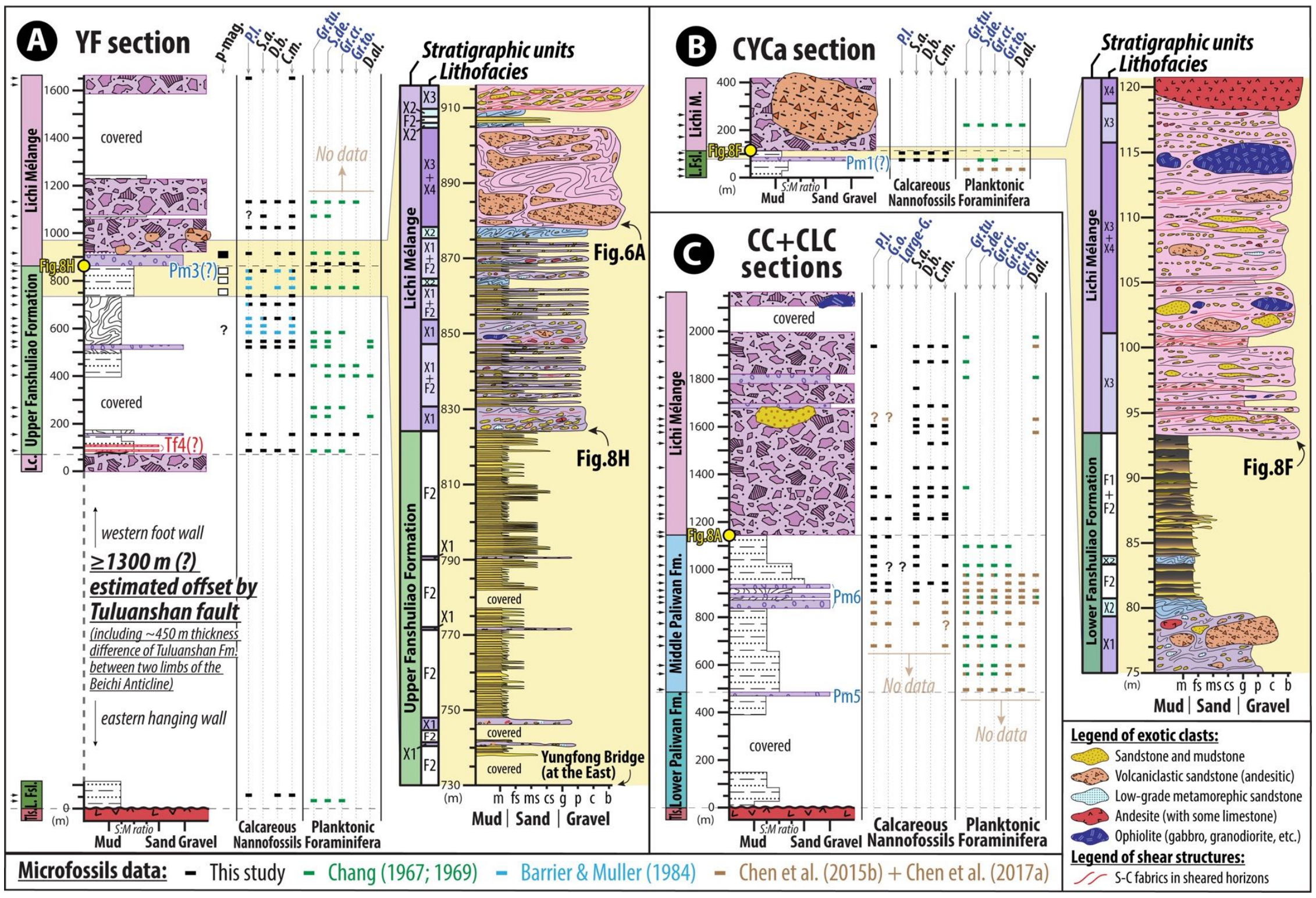

Figure 10. Selective sections showing stratigraphic columns and lithofacies changes in the depositional transitions between Lichi Mélange and other sedimentary units. (A) Yungfong (YF) section and measured depositional contact zone; (B) Chungye river - A (CYCa) section and measured depositional contact zone; (C) synthesis of the Chunchie river (CC) and Chiaolai river (CLC) sections. Lithological legends and abbreviation of magneto-biostratigraphy follow Fig. 9. Yellow circles mark the depositional contact zones shown in Figs. 8. Chiaolai river (CLC) sections. Lithological legends and abbreviation of magneto-biostratigraphy follow Fig. 9. Yellow circles mark the depositional contact zones shown in Figs. 8.
Black arrow heads on the left mark the stratigraphic heights where magneto-biostratigraphic constraints exist. See details of sample numbers, microfossils data, and measured contact zone photos in Figs. S12, S13, S15, S16, and Tables S3, S4. 


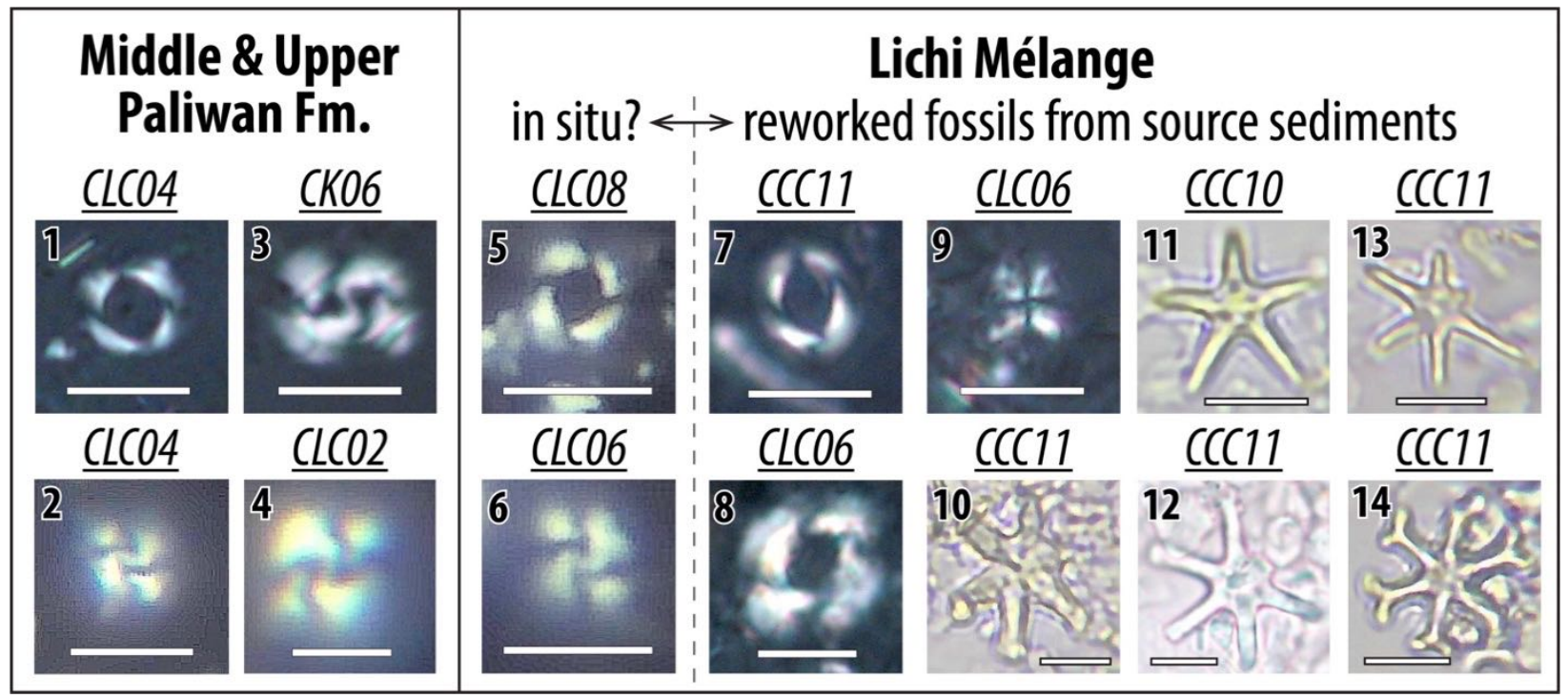

Figure 11. Polarizing micrographs of index calcareous nannofossils, recovered from Paliwan Formation, and overlying Lichi Mélange, with scale bars of $5 \mu \mathrm{m}$. Photo numbers 1 and 5 are Pseudoemiliania lacunosa. Numbers 2 and 6 are Gephyrocapsa oceanica. Numbers 3 and 4 are large Gephyrocapsa sp. Numbers 7 and 8 are medium and large forms of Reticulofenestra pseudoumbilicus respectively. Number 9 is Sphenolithus abies. Number 10 is Discoaster druggii (?). Number 11 is Discoaster quinqueramus. Number 12 is Discoaster surculus. Number 13 is Discoaster brouweri. Number 14 is Discoaster variabilis. See sample locations in Figs S5, S7 and Table S3. 


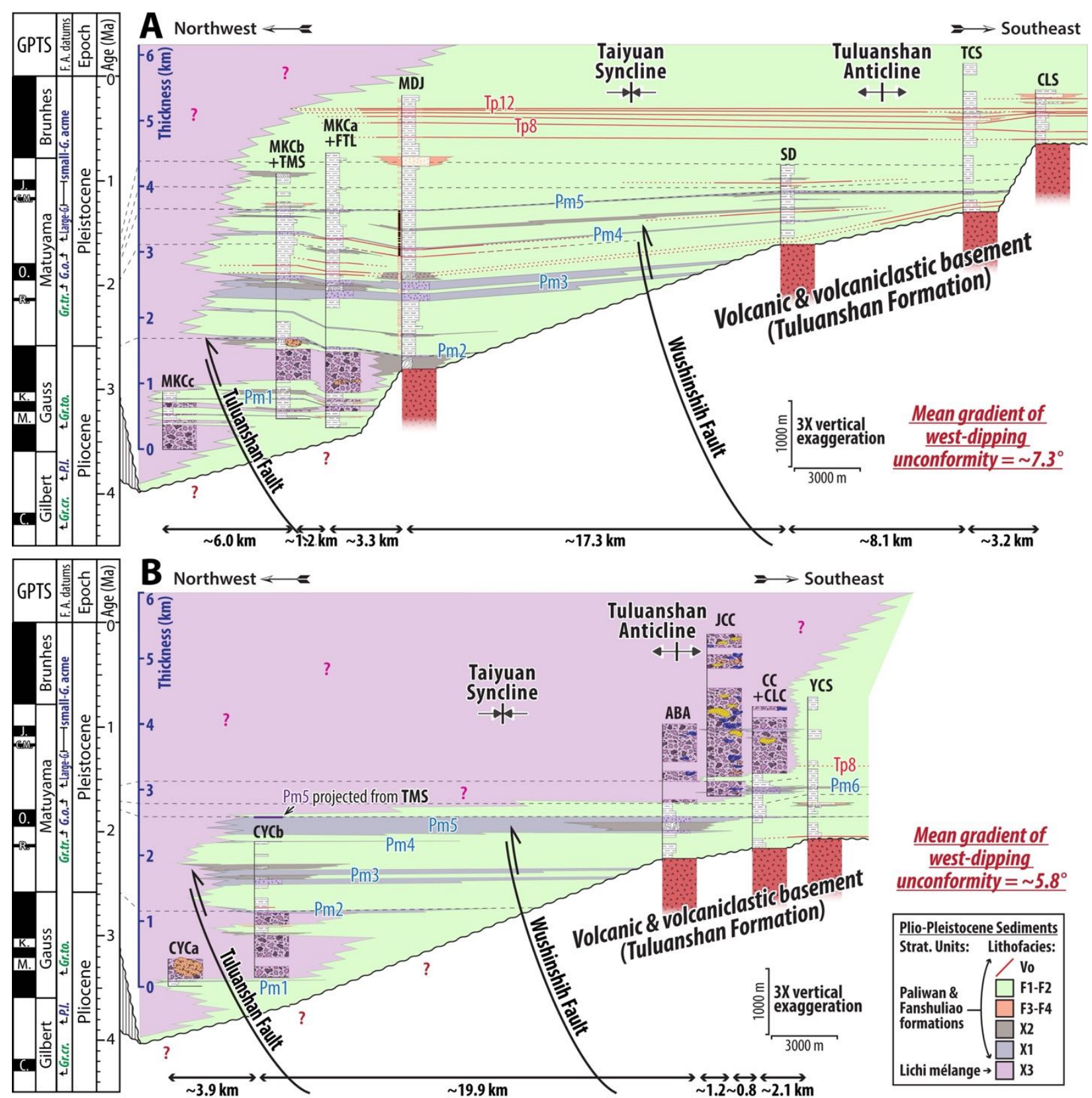

Figure 12. Stratigraphic panels of southern Taiyuan area, with restored distances between stratigraphic sections. (A) PowhuaShinchang transect; (B) Luye-Tulan transect. Black and white rectangles with red outlines along the Madagida river (MDJ) section show paleomagnetic polarities. See locations of transects in Fig. 4. See details of litho-bio-magnetostratigraphic information in 


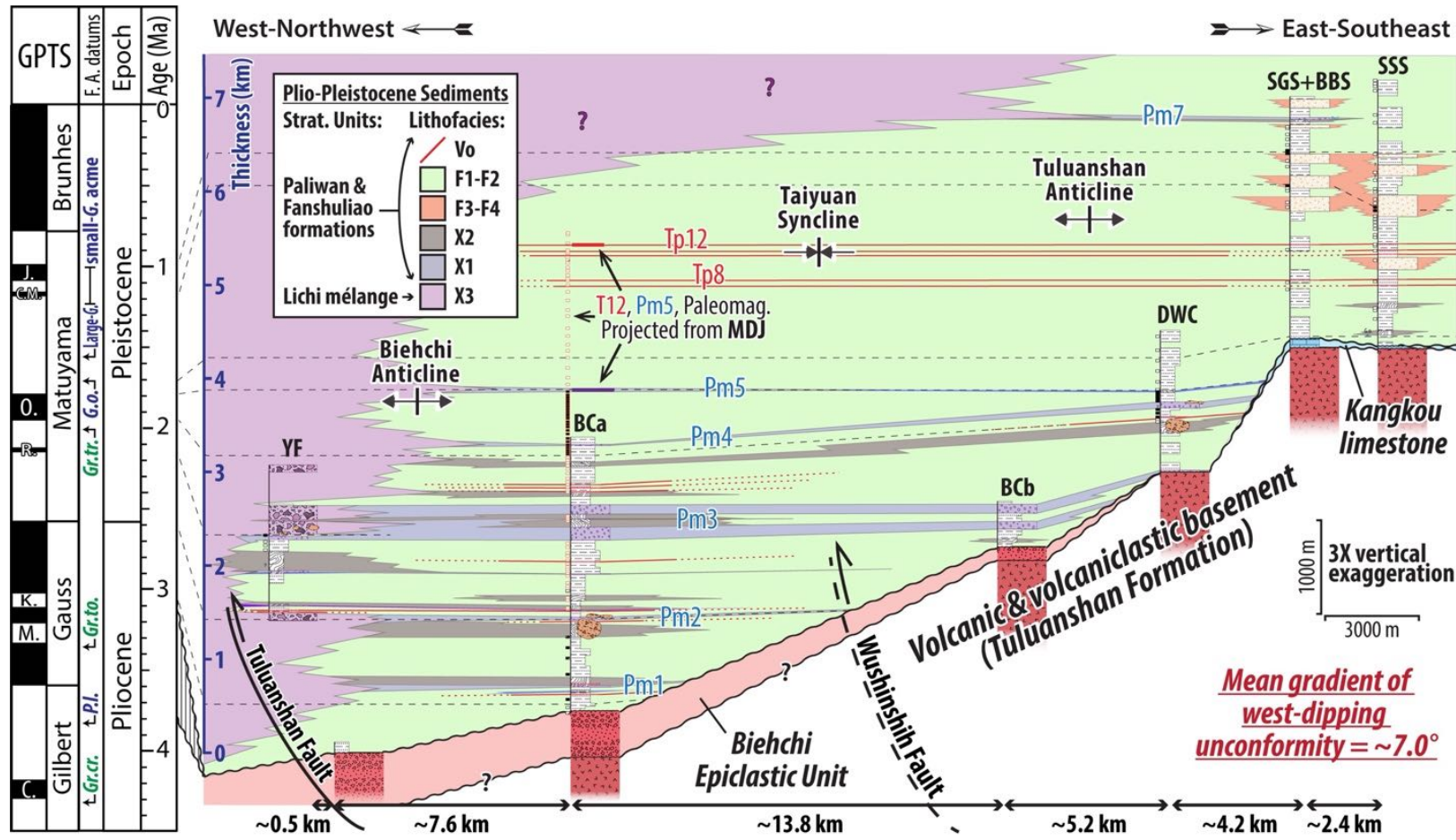

Figure 13. Stratigraphic panel of Fuli-Chengkung area, with restored distances between stratigraphic sections. Black and white rectangles with red outlines show paleomagnetic polarities of Bieh river - A (BCa), Duwei river (DWC), Shingang river (SGS), of the transect in Fig. 4. See details of litho-bio-magnetostratigraphic information in Figs. S12-S14. 


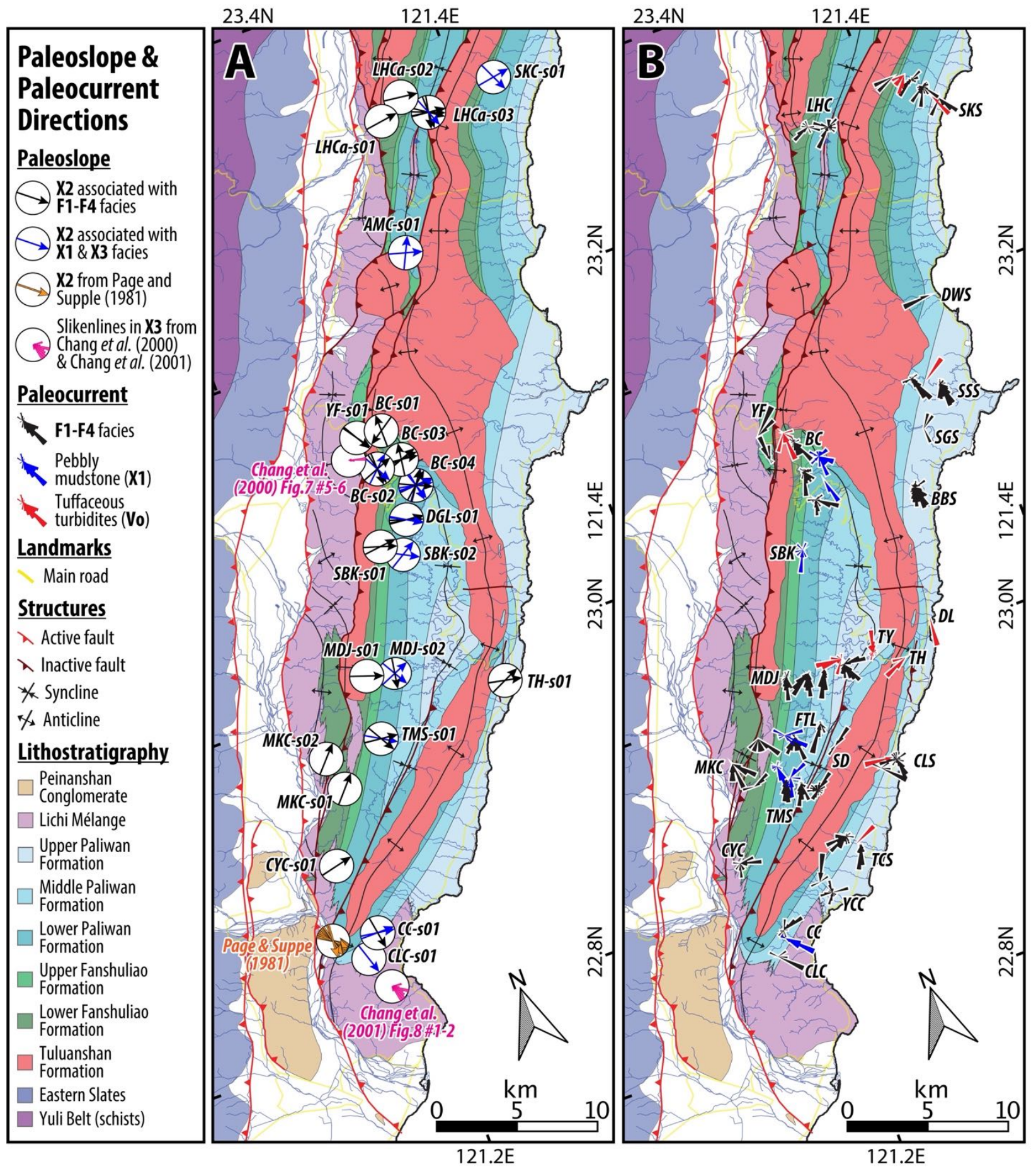

Figure 14. (A) Inferred paleoslope direction from plunging direction of slump folds (facies X2), including results from Page and Suppe (1981), and bedding corrected east-vergent slikenline shearing sense in basal shear horizons of olistostrome (facie X3) (Chang et al., 2000, 2001); (B) Inferred paleocurrent direction from imbrication, cross-lamination, and flute cast. See method details in text. See raw data, locations, and used structural restorations in the Tables S1, S2. 

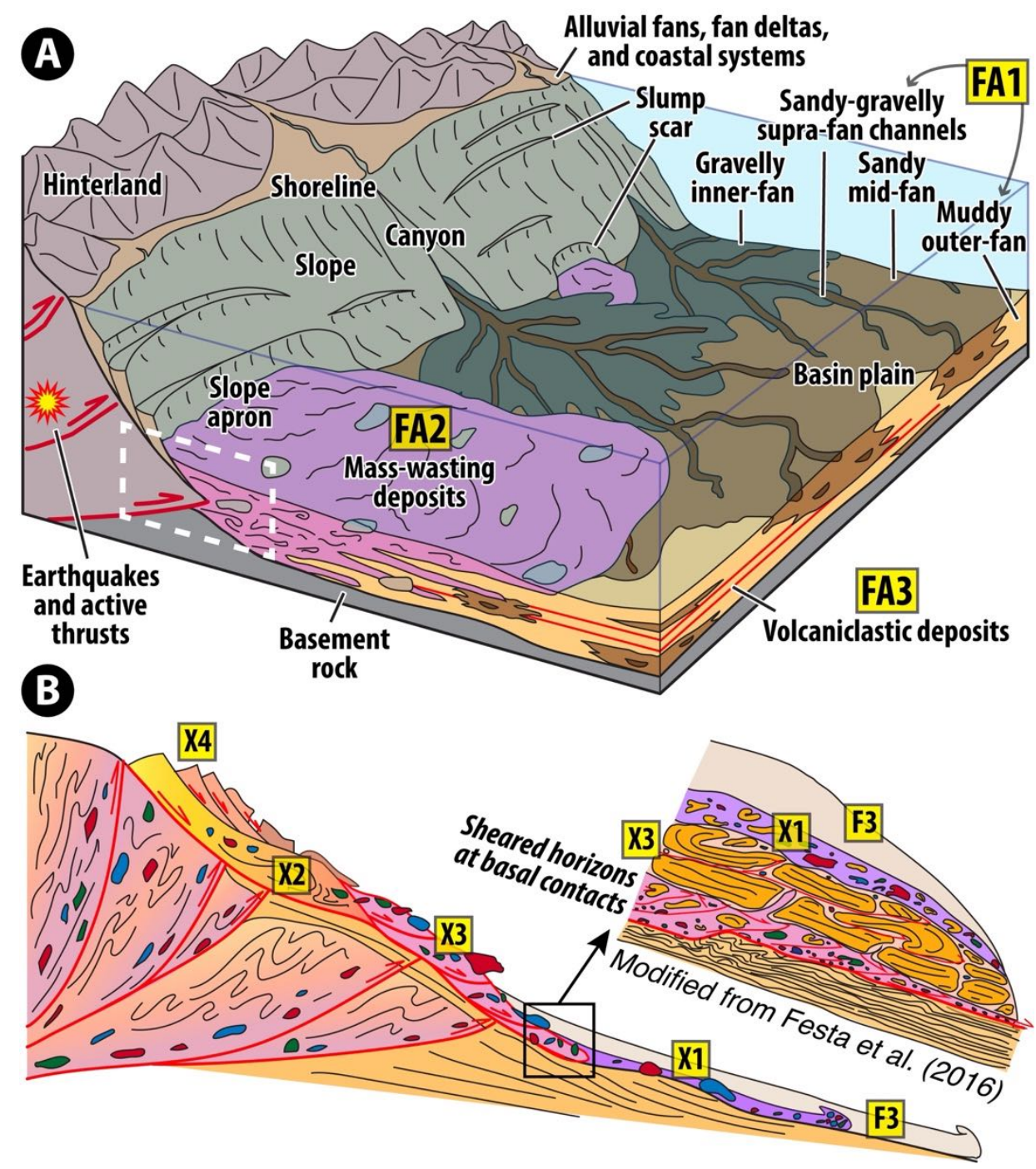

Figure 15. Lithofacies classification scheme. (A) Depositional environment model (modified from Stow and Mayall, 2000) and facies associations (FA1-3) of the Coastal Range sedimentary rocks. White dash box marks the place where mélange-forming processes are portrayed in B; (B) Facies model (modified from Festa et al., 2016; Ogata et al., 2012) for mass-wasting deposits (facies association FA2) and structurally orientated shears (facies association FA3). See detail descriptions of lithofacies and facies associations in Tables 1, 2. 


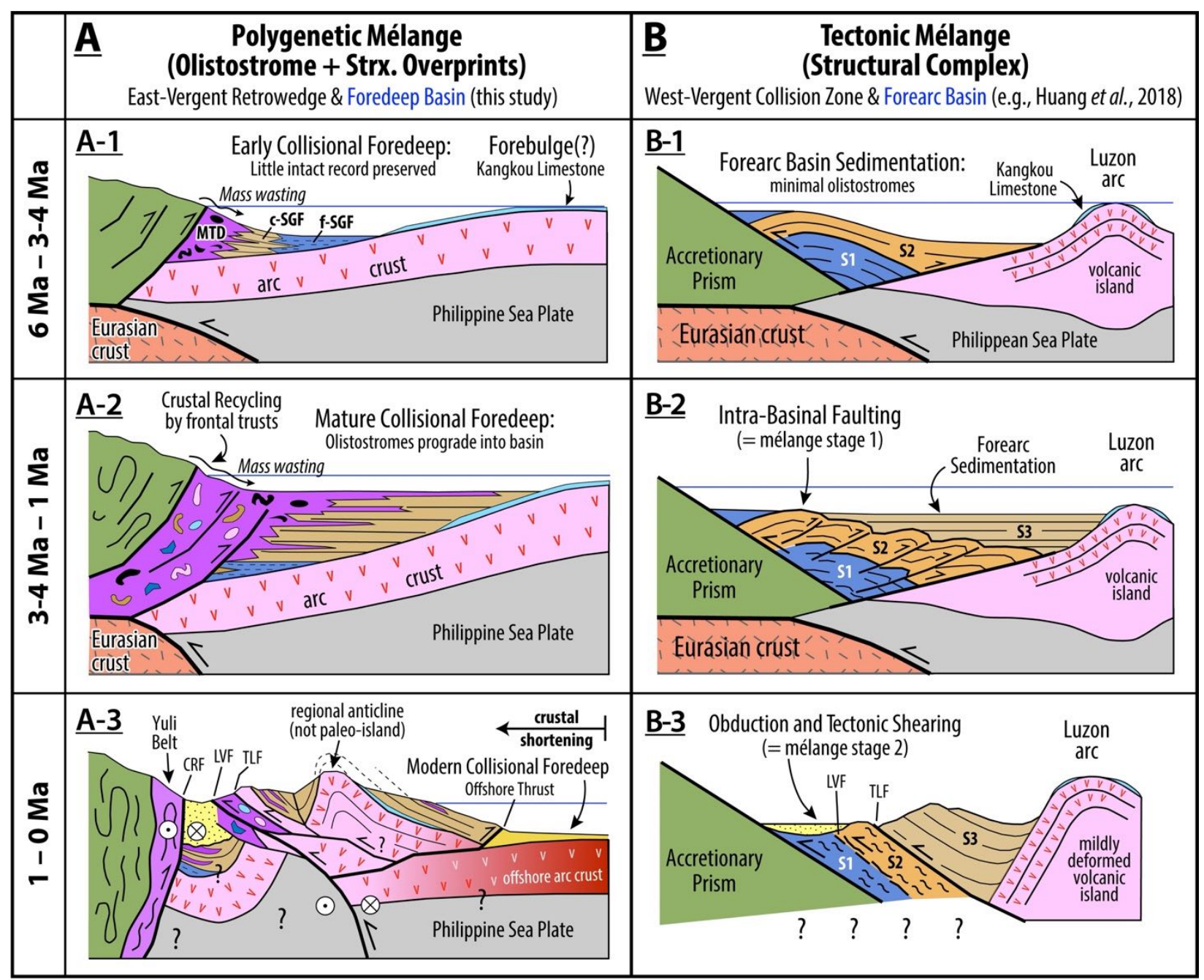

Figure 16. Synthetic comparison of the two end-member models interpreting the role, age, and evolution of the Lichi Mélange. (A) Olistostromal origin model. Details are synthesized from several publications (Page and Suppe, 1981; Dorsey and Lundberg, 1988; Chi et al., 2014; Malavieille et al., 2016) and this study. MTD is mass-transport deposits (facies association FA2). Coarse- and fine-grained facies of cohesionless sediment gravity flows (facies association FA1) are marked as c-SGF and f-SGF respectively. CRF is the Central Range Fault (Shyu et al., 2006). LVF is the Longitudinal Valley fault. TLF is the Tuluanshan fault; (B) Tectonic origin model. Figures are modified from Huang et al. (2018) which summarized various versions to date. S1 to S3 represent 
1315 Table 1. Lithofacies of sedimentary rocks in the southern Coastal Range. See photos in Fig. 5-6.

\begin{tabular}{|c|c|c|c|c|}
\hline Facies Name & Summary Description & $\begin{array}{l}\text { Interpreted } \\
\text { Processes }\end{array}$ & $\begin{array}{l}\text { Strat. } \\
\text { Unit }\end{array}$ & $\begin{array}{l}\text { Mél } \\
\text { ange } \\
\text { Fab } \\
\text { ric }^{\dagger}\end{array}$ \\
\hline $\begin{array}{l}\text { F1: } \\
\text { Mudstone }\end{array}$ & $\begin{array}{l}\text { Dark gray to black mudstone (clay-silt mixture) with rare very thin beds of siltstone to } \\
\text { fine-grained sst. Internally structureless to weakly laminated, commonly includes } \\
\text { slump zones } \sim 0.5 \text { to } 5 \mathrm{~m} \text { thick. Clay is orogen-derived. }\end{array}$ & $\begin{array}{l}\text { Suspension } \\
\text { settling }\end{array}$ & $\begin{array}{l}\text { Fsl, } \\
\text { Plw }\end{array}$ & $\alpha$ \\
\hline $\begin{array}{l}\text { F2: } \\
\text { Turbidites }\end{array}$ & $\begin{array}{l}\text { Sandstone and mudstone in laterally continuous beds. Sst beds } \sim 0.01 \text { to } 0.5 \mathrm{~m} \text { thick, } \\
\text { normally graded with Bouma sequence, variable sand:mud ratio. Sandstone } \\
\text { composition dominantly orogen-derived lithic fragments. }\end{array}$ & $\begin{array}{l}\text { Low-density } \\
\text { turbidity } \\
\text { current }\end{array}$ & $\begin{array}{l}\text { Fsl, } \\
\text { Plw }\end{array}$ & $\alpha$ \\
\hline $\begin{array}{l}\text { F3: } \\
\text { Thick-bedded } \\
\text { sandstone and } \\
\text { gritstone }\end{array}$ & $\begin{array}{l}\text { Normally graded massive to laminated sandstone beds } \sim 0.5 \text { to } 5 \mathrm{~m} \text { thick. Granule } \\
\text { conglomerate (grit) and pebbly sandstone in lower parts of thicker beds. Large flame } \\
\text { and dish structures common near base. Sandstone and clast composition dominated by } \\
\text { orogen-derived lithic fragments. }\end{array}$ & $\begin{array}{l}\text { High-density } \\
\text { turbidity } \\
\text { current }\end{array}$ & $\begin{array}{l}\text { Fsl, } \\
\text { Plw }\end{array}$ & $\alpha$ \\
\hline $\begin{array}{l}\text { F4: } \\
\text { Conglomerate }\end{array}$ & $\begin{array}{l}\text { Clast-supported conglomerate with pebble to boulder sized clasts, indistinct normal or } \\
\text { inverse to normal grading near base. Beds } \sim 1 \text { to } 5 \mathrm{~m} \text { thick. Bases of beds are planar to } \\
\text { channelized. Clasts primarily well-rounded low-grade metasandstone and subangular } \\
\text { to rounded andesite with trace amounts of mafic rocks (e.g., basalt, gabbro). }\end{array}$ & $\begin{array}{l}\text { Non-cohesive } \\
\text { debris flow } \\
\text { (grain flow) }\end{array}$ & $\begin{array}{l}\text { Fsl, } \\
\text { Plw }\end{array}$ & $\alpha$ \\
\hline $\begin{array}{l}\text { X1: } \\
\text { Pebbly } \\
\text { mudstone }\end{array}$ & $\begin{array}{l}\text { Matrix-supported, structureless pebbly mudstone in } \sim 0.2 \text { to }>300 \mathrm{~m} \text { thick beds. } \\
\text { Bimodal grain-size (mud and gravel), minor sand. Pebble- to boulder-size clasts are } \\
\text { angular to subangular andesite \& limestone, and subrounded to well-rounded } \\
\text { metasandstone and mafic to ultramafic volcanic rocks, unoriented to locally imbricated. } \\
\text { Clast-rich and clast-poor zones alternate within single beds. Large flame structures } \\
\text { common at base of beds. }\end{array}$ & $\begin{array}{l}\text { Cohesive debris } \\
\text { flow or slurry } \\
\text { flow }\end{array}$ & $\begin{array}{l}\text { Fsl, } \\
\text { Plw }\end{array}$ & $\alpha ?$ \\
\hline $\begin{array}{l}\text { X2: } \\
\text { Slump bed }\end{array}$ & $\begin{array}{l}\text { Ductilely deformed, convoluted and distorted sedimentary intervals } \sim 0.3 \text { to } 120 \mathrm{~m} \\
\text { thick. Local fragmented and dismembered sandstone present in locally sheared matrix } \\
\text { (i.e., broken formation) with common structures like pinch-and-swell, ductile to quasi- } \\
\text { brittle boudinage, and extensional fractures. Poorly-to-well developed S-C fabrics and } \\
\text { scaly foliation observed in less competent fine-grained layers. Protolith is mainly } \\
\text { turbidites (F2) with abundant soft-sediment deformation such as micro-faulting and } \\
\text { asymmetrically inclined recumbent folds with open to s-shaped fold profile. }\end{array}$ & $\begin{array}{l}\text { Submarine } \\
\text { slope failure, } \\
\text { slides, and } \\
\text { slumps, with } \\
\text { sedimentary } \\
\text { (gravitational) } \\
\text { shearing }\end{array}$ & $\begin{array}{l}\text { Fsl, } \\
\text { Plw }\end{array}$ & $\underset{\gamma}{\alpha, \beta}$ \\
\hline $\begin{array}{l}\text { X3: } \\
\text { Olistostrome }\end{array}$ & $\begin{array}{l}\text { Laterally extensive zones of chaotic, matrix-supported, unsorted to weakly bedded } \\
\text { sedimentary mélange } \sim 30 \text { to }>500 \mathrm{~m} \text { thick. Dismembered sedimentary rocks (similar } \\
\text { to facies F2) with extra-formational clasts in pervasively deformed fine-grained matrix. } \\
\text { S-C fabrics, scaly foliation, and mildly developed slickensides commonly occur in } \sim 1 \\
\text { to } 10 \text { meters thick (wide) sheared horizons near the basal contacts, with common } \\
\text { structures like pinch-and-swell, ductile to quasi-brittle boudinage, and extensional } \\
\text { fractures. Tabular to elongated clasts are aligned parallel to the scaly fabric. Bimodal } \\
\text { grain-size (mud and gravel), minor sand. Matrix dominantly gray to moss green clays } \\
\text { "ccolor bands"). Larger clasts display variable rounding. Locally brecciated matrix } \\
\text { close to basal shear horizons and cross-cutting faults. Diverse clast compositions: } \\
\text { andesite, volcaniclastic sandstone and conglomerate, well-lithified quartz-rich } \\
\text { sandstone without orogen-derived lithic fragments, ophiolitic rocks (gabbro, } \\
\text { serpentinite, granodiorite, etc.), limestone, metasandstone. }\end{array}$ & $\begin{array}{l}\text { Blocky flow } \\
\text { and cohesive } \\
\text { debris flow } \\
\text { with } \\
\text { sedimentary } \\
\text { brecciation, } \\
\text { shearing, and } \\
\text { rock-mixing }\end{array}$ & $\mathrm{Lc}$ & $\delta$ \\
\hline $\begin{array}{l}\text { X4: } \\
\text { Olistolith }\end{array}$ & $\begin{array}{l}\text { Decimeter- to km-scale single allochthonous block in slumped mudstone. } \\
\text { Compositions include andesite, volcaniclastic sandstone and conglomerate, ophiolitic } \\
\text { rocks (gabbro, serpentinite, granodiorite, etc.), limestone, and quartz-rich sandstone to } \\
\text { low-grade metasandstone. Blocks commonly contain internal brittle shears and } \\
\text { fractures with local diapiric mudstone intrusions. }\end{array}$ & $\begin{array}{l}\text { Submarine } \\
\text { rock slide or } \\
\text { avalanche }\end{array}$ & $\begin{array}{l}\text { Fsl, } \\
\text { Plw, Lc }\end{array}$ & $\begin{array}{l}\alpha ?, \\
\delta ?\end{array}$ \\
\hline $\begin{array}{l}\text { Vo: } \\
\text { Tuffaceous } \\
\text { turbidites }\end{array}$ & $\begin{array}{l}\text { White normally graded, planar to ripple-laminated tuffaceous sandstone, with Bouma } \\
\text { sequence, in beds } \sim 0.01 \text { to } 7 \mathrm{~m} \text { thick. Grain size is silt to very-coarse sand with rare } \\
\text { small pebbles near base. Grains are mostly fresh felspar with locally abundant dark } \\
\text { minerals (biotite, pyroxene, hornblende) and volcanic lithic fragments. Minor glass } \\
\text { shards at tops of some beds. }\end{array}$ & $\begin{array}{l}\text { Syn-eruptive } \\
\text { turbidity } \\
\text { current }\end{array}$ & $\begin{array}{l}\text { Fsl, } \\
\text { Plw }\end{array}$ & $\alpha$ \\
\hline
\end{tabular}


1320 Table 2. Facies associations of sedimentary rocks in the southern Coastal Range.

\begin{tabular}{|c|c|c|c|}
\hline $\begin{array}{l}\text { Facies } \\
\text { Association }\end{array}$ & Occurrence and Lithofacies Contacts & Depositional Setting & $\begin{array}{l}\text { Rock } \\
\text { Unit }\end{array}$ \\
\hline $\begin{array}{l}\text { FA1: } \\
\text { Cohesionless } \\
\text { sediment } \\
\text { gravity flows }\end{array}$ & $\begin{array}{l}\text { Submarine flysch facies F1 to F4 (Fig. 5A-C). F1 = distal basin } \\
\text { plain and slope. Base of beds in all facies are typically sharp } \\
\text { (erosive). Facies F3 and F4 locally display channelized bases with } \\
\sim 2 \text { to } 230 \mathrm{~m} \text { deep and 10's to 100's m wide erosional channels } \\
\text { incised into facies F1 and F2. }\end{array}$ & $\begin{array}{l}\text { Proximal to distal } \\
\text { submarine fan with } \\
\text { supra-fan channels, and } \\
\text { distal basin plain. }\end{array}$ & $\begin{array}{l}\text { Fsl, } \\
\text { Plw }\end{array}$ \\
\hline
\end{tabular}

Interbedding, soft-sediment deformation, and lateral transitions among pebbly mudstone (X1), slump bed (X2), and/or olistostrome (X3) (Figs. 5E-F, 6D-E), with randomly distributed lithic blocks (X4) (Fig. 6A-C).

\section{Observed Basal Contact Styles :}

(1) Base of facies X1, X3, and X4, where resting on FA1, is sharp and erosive (Fig. 8A, 8G), locally with sheared horizons (Fig. 8F-G). Facies X3 locally onlap or downlap onto incised channel margins (Fig. 8E).

\section{FA2:}

(2) Base of facies X1 and X3 transitional from X2 (Fig. 5E).

Submarine mass wasting and cohesive debris flows and gritstone $(\mathrm{F} 3)$.
(3) Base of facies X1 transitional from thick-bedded sandstone

(4) Diapiric intrusions of mixed underlying strata at the margins of X4 (Fig. 6A-C).

\section{Observed Upper Contact Styles:}

(1) Upper contact of facies X1, X2, X3, and X4 where overlain by facies association FA1 is sharp (Fig. 8B-D).

(2) Upper and lateral margins of facies X4 commonly surrounded by facies X1, X2, and X3 (Figs. 6A-E, 10A-B).

(3) Upper contact of facies X1 gradually transitional to thickbedded sandstone and gritstone (F3).

(4) Upper contact of facies X3 transitional to X2.

\section{FA3:}

Volcaniclastic deposition
Fresh tuffaceous sandstone beds (Vo) with sharp erosive bases. Primarily interbedded with turbidites (F2), uncommonly preserved where facies other than F2 are dominant (Fig. 5D).
Muddy sediment-rich, mass-transport complex derived from steep slope and deposited at base of slope to proximal basin floor. Local brittle and plastic deformation zones Lc, record shearing on Fsl, discrete basal surfaces Plw of large mass movements. Variable degrees of sediment liquefication and lubrication that facilitated mass transport.

Distal syn-eruptive Fsl, turbidity currents. 